\title{
Tournament incentives and corporate fraud
}

\author{
Lars Helge Haß ${ }^{*}$ Maximilian A. Müller ${ }^{\dagger}$ Skrålan Vergauwe
}

This version: July 7, 2015

\begin{abstract}
This paper identifies a new incentive for managers to engage in corporate fraud stemming from the relative performance evaluation feature of CEO promotion tournaments. We document higher propensities to engage in fraud for firms with strong tournament incentives (as proxied for by the CEO pay gap). We posit that the relative performance evaluation feature of CEO promotion tournaments creates incentives to manipulate performance, while the option-like character can motivate managers to engage in risky activities. We thereby extend previous corporate fraud literature that focuses mainly on equity-based incentives and reports mixed findings. Our results are robust to using different fraud samples, and controlling for other known determinants of fraud as well as manager skills.
\end{abstract}

JEL Classification: J33; G30; M53

Keywords: Corporate fraud, tournament incentives, CEO pay gap

\footnotetext{
* Lancaster University Management School, Lancaster University, LA1 4YX, Lancaster, United Kingdom, Phone: +44 1524 - 593981, Fax: +44 1524 847321, e-mail: 1.h.hass@lancaster.ac.uk.

$\dagger$ WHU - Otto Beisheim School of Management, Burgplatz 2, 56179 Vallendar, Germany, Phone +49 2616509 - 232, Fax +49 2616509 239, e-mail: maximilian.mueller@whu.edu.

¥ Lancaster University Management School, Lancaster University, LA1 4YX, Lancaster, United Kingdom, Phone: +44 1524 - 594738, Fax: +44 1524 847321, e-mail: s.vergauwe @lancaster.ac.uk.
}

Acknowledgements: We are grateful to Stuart Gillen (editor) and an anonymous referee for very helpful suggestions. We thank Douglas Cumming, Frank Li (discussant), Tingyu Zhou, seminar participants at Exeter, and the participants at the CFA-JCF-Schulich Conference on Financial Markets Misconduct for valuable feedback. 


\title{
Tournament incentives and corporate fraud
}

\begin{abstract}
This paper identifies a new incentive for managers to engage in corporate fraud stemming from the relative performance evaluation feature of CEO promotion tournaments. We document higher propensities to engage in fraud for firms with strong tournament incentives (as proxied for by the CEO pay gap). We posit that the relative performance evaluation feature of CEO promotion tournaments creates incentives to manipulate performance, while the option-like character can motivate managers to engage in risky activities. We thereby extend previous corporate fraud literature that focuses mainly on equity-based incentives and reports mixed findings. Our results are robust to using different fraud samples, and controlling for other known determinants of fraud as well as manager skills.
\end{abstract}

JEL Classification: J33; G30; M53

Keywords: Corporate fraud, tournament incentives, CEO pay gap 


\section{Introduction}

Corporate fraud can have huge costs for shareholders, as evidenced by drops in market value of as high as $38 \%$ for firms accused of such behavior (Karpoff, Lee, and Martin, 2008a). To mitigate those costs, it is important to explore the incentives that lead to fraudulent behavior in corporations. Prior literature has primarily investigated how equity-based incentives of CEOs impact the propensity to commit fraud. While CEO behavior will respond exclusively to performance-based incentives, lower ranked executives (e.g., VPs) will respond both to performance-based incentives and to incentives stemming from the opportunity to get promoted to the CEO position and receive increased compensation, that is, promotion-based tournament incentives (e.g., Green and Stokey, 1983; Baker, Jensen, and Murphy1988).

Rank-order tournaments are schemes of relative performance evaluation because the best relative performer wins and will receive the tournament prize. Tournament theory evolved as a way to explain the large pay gaps between the CEO and lower ranked executives commonly observed in practice and receiving considerable media attention. Lazear and Rosen (1981) have derived analytically that tournaments are optimal labor contracts, and they demonstrate a positive relationship between the effort made by agents and the magnitude of the tournament prize. Additionally, pay gaps provide a solution to the agency problems associated with monitoring difficulties that can prevent linking executive compensation to marginal product, such as, managerial shirking (Henderson and Frederickson, 2001). Consistent with this finding, Kale, Reis, and Venkateswaran (2009) find that tournament incentives are positively associated with firm performance. This literature commonly proxies for tournament incentives (the promotion prize) using the pay gap between the CEO and lower ranked executives (VPs).

Cheng (2011) presents analytical and empirical evidence that schemes of relative performance evaluation can lead to financial misreporting, because executives try to manipulate the learning process about their abilities due to career concerns. Furthermore, 
Goel and Thakor (2008) show analytically that executives faced with tournament incentives tend to take on greater risks to increase their promotion probability. Greater risk-taking incentives may translate into more efficient operating and financial policies, but Armstrong et al. (2013) find that such incentives may also increase the incidence of financial misreporting activities.

Finally, experimental studies document that stronger tournament incentives lead to more sabotage (Harbring and Irlenbusch, 2011) and cheating, e.g., in the form of dishonest performance reporting (Conrads et al., 2014). Accordingly, this paper tests whether tournament incentives are positively associated with a propensity to engage in fraudulent behavior.

We investigate this question by using a sample of reported fraud cases in large U.S. companies between 1994 and 2004, as identified in Dyck, Morse, and Zingales (2010). In order to measure tournament incentives, we follow prior literature and use the pay gap between the CEO and the median VP. We expect to find larger pay gaps for fraud firms than for non-fraud firms.

We find that fraud firms, on average, have significantly larger pay gaps than non-fraud firms. Multivariate tests confirm our prediction of a positive association between tournament incentives and the propensity to engage in fraudulent behavior. Our results also suggest an economically meaningful effect of tournament incentives relative to other fraud determinants.

These results are robust to using different matching methods, including industry fixed effects (Erickson, Hanlon, and Maydew, 2006) and random effects (Lennox and Pittman, 2010). We also document the robustness of our findings to using alternative pay gap measures, controlling for VP ability and to the inclusion of variables related to corporate governance quality and CEO power (e.g., Chen et al., 2006; Bebchuk, Cremers, and Peyer, 2011). We further confirm the external validity of our findings based on the Dyck, Morse, and Zingales (2010) fraud sample by replicating a positive association between tournament 
incentives and the propensity to engage in fraud using firms named in SEC Accounting and Auditing Enforcement Releases (AAERs). To address the limitation that our primary measure of fraud captures the joint event of a firm engaging in fraud and being caught, we replicate our findings using the likelihood of misreporting as the dependent variable (Dechow et al., 2011).

Taken together, our results suggest that one potential drawback of providing tournament incentives is an increased propensity to engage in fraud. This finding contributes to the literature that investigates dysfunctional consequences as a response to increased incentives (Holmström and Milgrom, 1991; Baker, 1992; Jacob and Levitt, 2003). Specifically, our results align closely with other papers that find a positive association between tournament incentives and excessive risk-taking (e.g., Knoeber and Thurman, 1994), sabotage, and cheating behavior. Our results also complement recent evidence that the use of relative performance evaluation schemes (across firms) can encourage fraud (Wang and Winton, 2012). Our results suggest that tournament incentives significantly influence VP behavior as firms with larger tournament incentives are more likely to engage in fraudulent activities.

Our study also contributes to the literature that investigates the determinants of corporate fraud, and, more specifically, compensation. Most of that work has focused on performance-based incentives of the CEO and other executives (e.g., Armstrong et al., 2013). We document the importance of tournament incentives in explaining the observed variation in fraudulent behavior across firms omitted by prior literature.

Our findings are subject to four primary limitations. First, we caution against a causal interpretation of our findings. Although we aim to address omitted variables bias and results remain robust, e.g., via different forms of matching, random effects estimation and controlling for CEO compensation, CEO power, and corporate governance, ultimately, we cannot rule out 
that some unobservable variable is correlated with the pay gap and a propensity to engage in fraud. ${ }^{1}$

Second, we use the pay gap to proxy for tournament incentives. This is in line with labor economics (Bognanno, 2001) and other papers in the finance literature that study the effect of tournament incentives on performance (Kale, Reis, and Venkateswaran, 2009) and risk-taking (Kini and Williams, 2012). However, other papers have used variants of the measure to capture different phenomena such as CEO power (Bebchuk, Cremers, and Peyer, 2011) or CEO skill (Masulis and Zhang, 2012). Although we control for these alternative explanations, we cannot rule out that our proxy may suffer from measurement error.

Third, our results indicate that larger pay gaps are associated with dysfunctional consequences, but we provide no evidence of whether the benefits of tournament incentives, documented by previous studies (e.g., Kale, Reis, and Venkateswaran, 2009; Faleye, Reis, and Venkateswaran, 2010), outweigh the costs. Our results suggest considering both the benefits and costs of tournament incentives when designing compensation contracts.

Finally, our results primarily refer to a sample of detected fraud cases. These cases are a function of (i) conducting fraud and (ii) the probability of being detected. To the extent that the probability of being detected is correlated with the pay gap, this would alter our inferences. Our results using the probability of misreporting as the dependent variable, however, document that this alternative explanation is less likely.

The remainder of this paper is structured as follows. In section 2, we develop a testable hypothesis for the association between the likelihood of fraud and the CEO pay gap. Section 3 discusses our sample selection procedure and our research design, while section 4 reports our empirical results. In section 5, we conduct a number of robustness tests, and consider alternative explanations. Section 6 summarizes and concludes.

\footnotetext{
${ }^{1}$ For example, Bereskin, Campbell, and Kedia (2014) and Cumming, Leung, and Rui (2015) show that corporate culture and board diversity may be associated with fraud.
} 


\section{Literature and hypothesis development}

\subsection{Fraud and incentives}

Both fraudulent behavior and managerial compensation have been topics of great interest and debate in practice and academia. The outsize number of detected fraud cases in recent years has led to regulatory changes, as well as to growing interest in the determinants and prevention of fraud due to the high costs to market participants (e.g., Ball, 2009; Karpoff and Lou, 2010; Kedia and Philippon, 2009).

Theory holds that individuals will only engage in fraudulent behavior if the benefits outweigh the costs. Previous literature has identified performance-based compensation, more specifically equity-based compensation, as such a benefit ${ }^{2}$. The traditional view is that equitybased compensation plans align the incentives of management and shareholders (Jensen and Meckling, 1976; Alexander and Cohen, 1999). However, prior research has argued that a manager whose wealth is more sensitive to changes in the firm's stock price has a greater incentive to engage in fraudulent activities such as financial misreporting.

For example, Goldman and Slezak (2006) develop an agency model in which stockbased compensation is a double-edged sword, inducing managers to work harder in some cases, but to engage in fraud in others. Bergstresser and Philippon (2006) find a positive relationship between the sensitivity of a CEO's equity portfolio to changes in stock price (delta) and earnings management; Burns and Kedia (2006) and Efendi, Srivastava, and Swanson (2007) find a positive relationship between a CEO's portfolio delta and earnings restatements. Erickson, Hanlon, and Maydew (2006) and Armstrong, Jagolinzer, and Larcker (2010) fail to find a positive relationship for all VPs or the CEO; Jiang, Petroni, and Wang (2010) find a relationship only for CFOs, not for CEOs. Finally, Bhattacharya and Marshall

\footnotetext{
${ }^{2}$ The costs to manangers include penalties, criminal charges, job loss, restrictions on future employment and fines (Karpoff, Lee, and Martin, 2008a; Ahorny, Liu, and Yawson, 2015).
} 
(2012) find that compensation and wealth is positively linked to the probability of being indicted as an illegal insider trader.

These mixed findings may arise because different measures of misreporting and research design were used (Armstrong, Jagolinzer, and Larcker, 2010), or because prior papers did not sufficiently control for detection mechanisms that mitigate the effect of equity incentives on misreporting (e.g., Jayaraman and Milbourn, 2014). Armstrong et al. (2013) summarize this research by considering portfolio vegas as an additional factor and find strong evidence of a positive relation between vega and misreporting. Overall, they document that equity portfolios can provide management with incentives to misreport because they make managers less averse to equity risk.

\subsection{Tournament incentives, the CEO pay gap, and fraud}

The literature discussed above primarily focuses on the role of CEOs and their performance-based incentives in fraud but usually does not take other VPs' tournament incentives into account. More recent evidence, however, indicates that VPs are also likely to be involved in financial misconduct (Jiang, Petroni, and Wang, 2010; Feng et al., 2011). Karpoff, Lee, and Martin (2008a, 2008b) document that 1,433 of 2,206 culpable employees in fraud cases were VPs, of which only a third (515) were CEOs. Hence, our primary objective is to examine whether tournament incentives contribute to explain VPs' engagement in fraudulent behavior.

Tournament theory offers an explanation for the large gaps between CEO pay and the pay of lower ranked executives observed empirically. These gaps are inconsistent with pay being linked to executives' marginal product. Instead, pay gaps ${ }^{3}$ provide a solution to the agency problems, such as managerial shirking (Henderson and Fredrickson, 2001), that can

\footnotetext{
${ }^{3}$ We define the CEO pay gap as the natural logarithm of the difference between CEO total compensation and median VP total compensation. One of the reasons we do not focus on the second highest paid executive is to avoid confounding incentives resulting from mutual monitoring, as documented by Li (2014).
} 
arise from monitoring difficulties. Similarly to equity-based compensation, they aim at aligning the goals and interests of management and shareholders (Lazear and Rosen, 1981).

While the proportion of equity incentives offered to VPs is growing (see Fuller and Jensen, 2002), VPs also face increasing promotion-based tournament incentives over time. ${ }^{4}$ In fact, a significant likelihood of insider succession ${ }^{5}$ exists in listed firms indicating that assuming a tournament scenario for the CEO position among VPs is plausible: Cremers and Grinstein (2014) document a 71\% probability of insider succession between 1993 and 2005 in US firms with only modest variation across industries.

Principals often set up rank-based pay, where pay gaps increase with each rank: The best relative performer is promoted to the next level in the hierarchy, while the others are passed over. These pay gaps are aimed at a better alignment of the interests of principals and agents: In such a tournament scheme, agents have strong incentives to perform well and expend greater efforts because this increases their chances of promotion. At the same time, this behavior increases a firm's output. Moreover, given that the pay gap increases with rank and the largest gap occurs between VPs and the CEO, promoted agents will still have incentives to perform well. Consequently, all VPs compete in a tournament to become the new CEO.

A large body of literature tests the analytical prediction by Lazear and Rosen (1981) that larger tournament prizes (i.e., higher pay gaps) lead to more effort. For example, Kale, Reis, and Venkateswaran (2009) and Chen, Ezzamel, and Cai (2011) find that tournament incentives are associated with better firm performance, while Bebchuk, Cremers, and Peyer (2011) find the opposite result. Mobbs and Raheja (2012) add to these mixed results by

\footnotetext{
${ }^{4}$ In our sample, the CEO pay gap increases on average by 4\% per year over the 1993-2004 period.

${ }^{5}$ The predictions of tournament theory continue to hold even though the pool of contestants for CEO promotion is not restricted to managers inside the firm. In general, non-CEO managers in the firm compete for the CEO position not only with other non-CEO managers inside the firm, but also with outsiders. Tournament theory predicts contestants will compete more strongly if the "prize" for winning the tournament is higher. Whether contestants are from inside the firm or from outside is irrelevant, as long as at least one insider competes in the tournament.
} 
showing that tournament incentives are important for firms where firm-specific human capital is not critical.

This paper tests whether increasing tournament incentives lead to dysfunctional responses, a prediction largely supported analytically and empirically in other contexts (Holmström and Milgrom, 1991; Baker, 1992; Jacob and Levitt, 2003). The specific dysfunctional consequences of employing a tournament may range from excessive risk-taking (e.g., Prendergast, 1999; and Knoeber and Thurman, 1994) and cheating (see Berentsen, 2002; and Cheng, 2011) to sabotage of other competitors (Lazear, 1989). ${ }^{6}$ Prior literature has documented that these activities are more likely to occur for higher tournament prizes. While Drago and Garvey (1998) document a decrease in helping effort, Garicano and PalaciosHuerta $(2006)^{7}$ and Harbring and Irlenbusch (2011) document greater effort and more sabotage activities for higher tournament prizes. $^{8}$

Cheng (2011) ${ }^{9}$ presents analytical and empirical evidence that managers inflate earnings to manipulate how the market learns about and judges their abilities - a situation comparable to that in a rank-order-tournament. Wang and Winton (2012) find that the use of relative performance evaluation in managerial retention decisions can encourage fraud. Experimental findings by Conrads et al. (2014) document a negative association between the level of honesty, as captured by participants' reporting of their own performance, and higher tournament prizes.

Finally, a strand of related literature focuses on tournament incentives and risk-taking. Nalebuff and Stiglitz (1983) and Ehrenberg and Bognanno (1990) argue that tournaments can

\footnotetext{
${ }^{6}$ While sabotage aims at diminishing competing managers' performance, cheating aims at increasing one's own performance relative to others' performance.

${ }^{7}$ Garicano and Palacios-Huerta (2006) study an exogenous change in the reward for a win in a soccer game from two to three points, and find more effort and more sabotage activities (as proxied for by the number of defenders and bookings).

${ }^{8}$ See Chowdhury and Gürtler (2013) and Dechenaux, Kovenock, and Sheremeta (2014) for a survey of studies on sabotage behavior in tournaments.

${ }^{9}$ Other analytical papers that illustrate a relationship between tournament incentives and cheating or doping are, for example, Berentsen (2002), Berentsen and Lengwiler (2004) and Kräkel (2007).
} 
potentially alter an individual's adoption of risky strategies. For example, in the mutual fund industry, managers are compensated against the market. Brown, Harlow, and Starks (1996) and Kempf and Ruenzi (2008) find these managers will reallocate their holdings to relatively risky assets depending on their interim positions in the tournament.

In an experimental design, Andersson et al. (2013) document that agents respond strongly to tournament incentives by increasing the principals' risk exposure. This result complements analytical work by Goel and Thakor (2008) who illustrate that the risk level of projects chosen by managers (CEOs and VPs) tends to increase with the promotion prize. Testing this prediction, Kini and Williams (2012) document a significantly positive relationship between firm risk and tournament incentives.

Overall, this literature concludes that tournament incentives can lead to higher risktaking. Armstrong et al. (2013) document that managers with greater risk-taking incentives are more likely to misreport because they are less averse to the increased equity risk that accompanies misreporting.

In summary, tournaments are based on relative performance evaluation and with increasing tournament incentives, dysfunctional responses, such as manipulating performance, become more likely. Because tournament incentives can also encourage higher risk-taking, managers will be less averse to the increases in equity risk induced by fraudulent behavior. Hence, we predict that:

H: Tournament incentives are positively associated with the likelihood of fraud.

\section{Sample selection and research design}

\subsection{Sample selection}

We use data from Dyck, Morse, and Zingales (2010) (hereinafter, DMZ) to determine our fraud firm sample. The DMZ dataset uses the Stanford Securities Class Action Clearinghouse collection to identify fraud cases, and consists of U.S. firms against which a 
securities class action lawsuit has been filed under the provisions of the Federal 1933/1934 Exchange Act for the 1994-2004 period. After applying several filters to ensure the cases considered are not frivolous, they obtain 216 fraudulent firms.

Untabulated results reveal that the fraud alleged in $75 \%$ of these cases is accountingbased. Hence, our study is closely related to prior literature on (accounting) fraud and equity compensation in restatement and enforcement action samples (e.g., Armstrong et al., 2013). In robustness tests presented later, we replicate our findings in other samples, and find our results are unchanged. We exclude multiple fraud occurrences per firm because we are only interested in the initial fraud year, which leaves us with 205 firms. After eliminating firms not covered in ExecuComp, we have 190 firms, and we have sufficient data from Compustat and ExecuComp to employ our research design for 111 firms.

Table 1 outlines our sample selection procedure. We use the beginning of the class action period, the year in which the firm allegedly began engaging in fraudulent behavior, to proxy for the fraud year.

[Table 1 about here]

Table 1 provides further information on our comparison sample. We select all available firm-year observations in ExecuComp not included in our fraud sample. For fraud firms, we delete observations after the fraud year. ${ }^{10}$ After further deleting observations with missing values on the control variables or test variables, we obtain 16,052 observations (111 fraud firm-years and 15,941 non-fraud firm-years). These observations relate to 2,309 unique non-fraud firms and 111 fraud firms, indicating a fraud probability, conditional on detection, of $4.6 \%$.

\footnotetext{
${ }^{10}$ Results are robust to including observations after the fraud year, and to assigning a value of 1 for each fraud year rather than assigning a 1 to the first fraud year only.
} 
Table 2 gives a breakdown of the fraud firms by year and industry. ${ }^{11}$ Almost half of our sample observations come from the period 1999-2001 corresponding to the dot-com bubble and subsequent market collapse but results are robust to including year fixed effects and to including a dot-com indicator variable. With respect to industry distribution, we find no obvious clustering by industry.

[Table 2 about here]

\subsection{Research design}

To examine the association between tournament incentives and the likelihood of fraud, we estimate a probit model following Armstrong et al. (2013). ${ }^{12}$ The dependent variable is a binary variable equal to 1 if the firm is classified as a fraud firm in the DMZ database and if it allegedly began fraudulent behavior in the respective year, and 0 otherwise. ${ }^{13}$ Following prior literature, all fraud determinants are measured one year prior to the measure of fraud. ${ }^{14}$

We measure the strength of a firm's tournament incentives as the difference between total CEO compensation and total median VP compensation (Kale, Reis, and Venkateswaran, 2009; Kini and Williams, 2012). More specifically,

$$
\text { CEO pay gap }=\operatorname{Ln}(\text { total } \mathrm{CEO} \text { compensation }
$$

- median value of total VP compensation).

\footnotetext{
${ }^{11}$ Note that all of our results hold when we exclude financial firms or observations prior to 1996. The Private Securities Litigation Reform Act (PSLRA) of 1995 established several provisions to increase the effectiveness of monitoring by institutional owners.

${ }^{12}$ Following Gow, Ormazabal, and Taylor (2010) and Thompson (2011), we use robust standard errors clustered at the firm and year level. We do note that these papers deal with OLS regression and not maximum likelihood estimation but our inferences are unchanged when using different clustering approaches.

${ }^{13}$ Probit regressions are based on maximum likelihood techniques which assume no serial correlation. Yet clustering is used to take care of non-independence of observations. Under certain conditions, this can lead to artificially low standard errors. We therefore rerun our main model without clustering and by using OLS with two-way clustering. Our results do not alter and we continue to find a positive significant coefficient for the CEO pay gap.

${ }_{14}^{14}$ Apart from age and binary variables, we winsorize all of the continuous control variables at the 1st and 99th percentiles.
} 
Our main analysis includes the top five VPs reported in ExecuComp for a given firmyear, but results are robust to the inclusion of all non-CEO executives.

We control for equity incentives of CEOs by including option intensity (Denis, Hanouna, and Sarin, 2006) in our analysis. ${ }^{15}$ We also include several other control variables related to the likelihood of fraud and litigation risk (as summarized by Kim and Skinner, 2012). First, to control for market-related incentives and strike suits, we include cumulative stock returns, return skewness, and turnover as controls (Johnson, Kasznik, and Nelson, 2000). We also include return volatility to control for firms operating in uncertain environments (Erickson, Hanlon, and Maydew, 2006). Second, we control for firm size and age by including the natural logarithm of total assets (e.g., Denis, Hanouna, and Sarin, 2006), and the number of years the firm appeared in Compustat (e.g., Armstrong et al., 2013). Third, we include sales growth, because firms with higher growth opportunities have greater financing needs (Wang, 2004). Fourth, we include return on assets and the book to market ratio to control for firm performance, because poorly performing firms may engage in fraud to cover up poor results (Erickson, Hanlon, and Maydew, 2006). Fifth, we include leverage, receivables, inventory, and intangibles (Erickson, Hanlon, and Maydew, 2006; Firth, Rui, and Wu, 2011; Armstrong et al., 2013). Sixth, we control for the need for external financing by including the amount of money raised through stock and debt (Armstrong et al., 2013). Seventh, we control for capital intensity by including net plant, property, and equipment scaled by total assets. Finally, we include an acquisition dummy equal to 1 if more than onefifth of sales in a year are related to an acquisition, and 0 otherwise. Further details on variable definitions are presented in Appendices 1 and 2.

Our primary estimation compares the sample of fraud firms against all other available non-fraud observations over the same time period. We also follow prior literature and

\footnotetext{
${ }^{15}$ See Appendix 1 for a complete description of and the formula for our option intensity measure.
} 
compare fraud firms against a sample of non-fraud firms matched by size, industry, and year (e.g., Erickson, Hanlon, and Maydew, 2006).

\section{The relationship between tournament incentives and fraud}

\subsection{Univariate comparison of tournament incentives}

Table 3 reports differences in CEO pay gaps for our sample of fraud firms, matched non-fraud firms, and the full sample. In panel A of Table 3, we compare the tournament incentives between fraud firms and all as well as non-fraud firms. In line with our prediction, we find a significant difference between tournament incentives for fraud relative to all as well as matched non-fraud firms. The average tournament incentives, measured as the natural logarithm of the CEO/median VP pay gap, are 8.10 (\$3.29 million) for fraud firms and 7.10 (\$1.21 million) for all non-fraud firms and 7.70 (\$2.21 million) for matched non-fraud firms. This difference is significant at the $1 \%$ and $5 \%$ level and also represents economically significant stronger tournament incentives for fraud firms.

\section{[Table 3 about here]}

Table 3 also compares the values of our control variables over the three samples (fraud firms, non-fraud firms, and matched non-fraud firms). For each variable, Table 3 shows the mean, median, standard deviation, and both upper and lower quartiles.

Comparing fraud and unmatched non-fraud firms reveals that fraud firms, on average, are larger, older, have higher leverage, higher sales growth rates, more receivables, and higher financing needs. Non-fraud firms have higher book to market ratios, return skewness, returns, turnover, return volatility, and more capital expenditures. We find no evidence that option intensity differs among fraud and non-fraud firms, nor is there a difference in return on assets, acquisitions made, intangible assets, or inventory level. 
Comparing the matched non-fraud and fraud firms, we only detect a difference for four of the seventeen variables. Fraud firms have a higher sales growth rate, higher financing needs, and a lower book-to-market ratio. We do note that apart from financing, the difference in averages is reduced significantly after matching. Contrary to the full sample, we find that fraud firms have higher option intensity than the matched firms. For these reasons, we include all control variables in our regressions for the matched sample.

\subsection{The relationship between tournament incentives and fraud}

The univariate results suggest a positive association between tournament incentives and the likelihood of engaging in fraudulent behavior. In this section, we estimate probit models in which our dependent variable is equal to 1 if the company started to engage in fraud, and 0 otherwise. Results are presented in Table 4.

Model 1 shows the results for a comparison of the fraud and non-fraud firms, excluding controls. We find a significantly positive association between the pay gap and the likelihood of fraud (significant at the $1 \%$ level).

In order to test our hypothesis, we include controls for size, desire for external financing, performance, return volatility, and other factors in Model 2; as described earlier. We find a significantly positive relationship between the CEO pay gap and the likelihood of fraud at the $1 \%$ level.

This result is both statistically and economically significant. The marginal effect of the pay gap is 0.14 percentage points. Accordingly, a $100 \%$ increase in the pay gap measure corresponds to a 0.14 percentage point increase in the probability of being fraudulent for the average firm, which is an increase of $37 \%$ relative to the mean predicted probability of engaging in fraud in our sample of $0.38 \%$. Put differently, an increase in the pay gap at its mean from 1.2 million by $100 \%$ to 2.4 million increases the probability of engaging in fraud in a given year from $0.38 \%$ to $0.52 \%$. 
With respect to the control variables, we find that sales growth is significantly positively associated with the propensity to engage in fraud in line with Armstrong et al. (2013). We also find that the coefficient on size is significantly positive. This result is consistent with Armstrong et al. (2013), Lennox and Pittman (2010), and Burns and Kedia (2006). Similarly to Lennox and Pittman (2010), we find that book to market is significantly negatively associated with the propensity to engage in fraud. Finally, we find that the coefficient on financing is significantly positive, which is in line with Erickson, Hanlon, and Maydew (2006) and Lennox and Pittman (2010). Moreover firms with lower return skewness are more likely to engage in fraud. For the other determinants, we find these are not significantly different from zero, which is overall consistent with the previous literature.

In Model 3, we compare the fraud firm sample against a sample of non-fraud firms matched by industry, size, and year. Our results hold: We find a significantly positive association between the CEO pay gap and the likelihood of fraud (significant at the 5\% level). Further, we note that none of the control variables is significant, confirming that our matching performs reasonably well in reducing observable differences between fraud and non-fraud firms.

[Table 4 about here]

\section{Robustness tests}

In this section, we test the robustness of our primary findings to alternative research designs, alternative measures of the CEO pay gap, non-CEO skills, alternative measures for equity-based incentives, and alternative samples.

\subsection{Alternative research design}


Table 5 follows different research designs proposed by prior literature to test the robustness of our results. Model 1 controls for unobservable firm characteristics, and shows the results of a random effects probit regression (Lennox and Pittman, 2010). Again, we find a significantly positive coefficient of the pay gap (1\% level). Model 2 is a logistic regression following Erickson, Hanlon, and Maydew (2006) that includes industry fixed effects to control for industry-related effects. ${ }^{16}$ Our results continue to hold (1\% level) after controlling for industry. Model 3 checks the robustness of our results against different types of matching. In this model, we use Lennox and Pittman's (2010) propensity score matching approach to control for differences between fraud and non-fraud firms in the year prior to engaging in fraud. To obtain a matched sample, we first estimate a fraud prediction model where the dependent variable indicates whether the company is about to commit a fraud, excluding our experimental variable (CEO pay gap). We perform a nearest neighbor propensity score match, and explore the influence of promotion-based tournament incentives on the likelihood of fraud across otherwise identical firms with equal probabilities of engaging in fraud. Our results again hold, and we find a significantly positive coefficient (10\% level).

All subsequent analyses are robust to the different research designs outlined above (Model 1-3), unless stated otherwise. Overall, these results render it less likely that the pay gap is capturing some omitted firm-specific characteristic that can explain fraud in the crosssection.

[Table 5 about here]

\subsection{Pay gap as a measure of tournament incentives}

\footnotetext{
${ }^{16}$ Results are robust to using the penalized likelihood method to reduce any small-sample bias in maximum likelihood estimation (Firth, 1993).
} 
Table 6 uses alternative measures for tournament incentives and controls for VP skills since differences in pay may be related to differences in VP ability (Masulis and Zhang, 2012). Our use of the median VP pay could overestimate tournament incentives if only one or two VPs have significantly higher pay and higher chances of obtaining promotions than the remaining VPs (Masulis and Zhang, 2012). To rule out this measurement error in our tournament incentive proxy, we use the natural logarithm of the difference in pay between the CEO and the mean VP instead. We also use the difference between CEO pay and the highest paid VP.

Our results remain unchanged as we continue to find significant results for the gap between the CEO and the highest paid VP (at the 1\% level in the full (Model 1a) and at the $5 \%$ level in the matched (Model 2a) model), and for the mean pay gap (at the 5\% level in both the full (Model 1b) and matched (Model 2b) model).

Finally, we control for non-CEO skills in Table 6, following Masulis and Zhang (2012). We include average team age, average team salary growth (\%), and average team salary growth. The results in Table 6 show that the pay gap remains significantly positive at the $1 \%$ level for the full Models $1 \mathrm{c}$ and 1d, and at the 5\% level for the remaining models when we include these additional control variables.

[Table 6 about here]

\subsection{Alternative measures for equity-based incentives}

In Table 7, we proxy for equity-based compensation by using the sensitivity of the CEO's (VP's) equity portfolio to changes in stock price (delta) and equity risk (vega). Specifically, the CEO (VP) delta is the natural logarithm of 1 plus the CEO portfolio delta (the average VP portfolio delta). Similarly, the CEO (VP) vega is the natural logarithm of 1 plus the CEO portfolio vega (the average VP portfolio vega). 
Following Core and Guay (2002), we calculate a portfolio delta (vega) as the dollar change in a VP's equity portfolio for a $1 \%$ change in stock price (firm stock return volatility). Given the low number of observations for which we have CFO compensation data, we only estimate the full model when additionally controlling for CFO delta and vega. We further note that untabulated results reveal no significant differences for the interaction between the CEO pay gap and our measures of equity-based compensation and, hence, do not report these in Table 7.

In Models 1a and 2a, we include both the CEO delta (vega) and the VP delta (vega), with largely unchanged inferences. We find that our results hold for the full sample (1\% level) and are marginally significant for the matched sample (p-value of 0.13). In Model 1b, we include both the CEO delta (vega) and the CFO delta (vega). Due to missing annual titles, we only retain fifty-three fraud firms with CFO data. However, our results remain robust (at the $5 \%$ level). Overall, we do not find strong evidence that our results are driven by CEO or CFO equity-based incentives.

[Table 7 about here]

\subsection{Corporate governance and CEO power}

Our measure of tournament incentives, the CEO pay gap, will likely be related to corporate governance mechanisms at the firm level, and corporate governance mechanisms themselves may be related to corporate fraud (e.g. Chen et al., 2006; Lo, Wong, and Firth, 2010). In order to account for this potentially correlated omitted variable, we include several control variables related to corporate governance quality in Table 8 .

First, we include the G-index following Gompers, Ishii, and Metrick (2003). Second, we include a binary variable to control for a classified board, which is equal to 1 if the directors are elected to staggered rather than annual terms, and 0 otherwise. Third, we control 
for board independence by including the number of independent directors over the total number of board members. These variables are obtained from Risk Metrics. We exclude firms with missing values on the governance variable, which further reduces our sample to sixtyeight fraud firms.

Table 8 presents the results. Our result of a positive association of tournament incentives with the likelihood of engaging in fraudulent behavior is robust to controlling for corporate governance measures in the full sample (Model 1a). We note that none of the corporate governance measures are significant. Given the low number of observations for which corporate governance data is available in our sample, we have low power in the matched sample and fail to find significant results (Model 2a). As an alternative to our matching approach based on size, industry, and year, we estimate Model 1a for the full sample including year and industry fixed effects and controlling for size to overcome this issue. Untabulated results of this alternative approach confirm a significantly positive coefficient of the pay gap (at the $1 \%$ level).

Bebchuk, Cremers, and Peyer (2011) argue that the pay gap captures CEO power or importance. Moreover, VPs may engage in fraud because they are succumbing to pressure from the CEO, not because they are seeking immediate personal financial benefits from their equity incentives (Feng et al., 2011).

We investigate this alternative explanation by including two CEO power measures: CEO-chairman duality and founder status (Feng et al., 2011). Duality is a binary variable that takes the value of 1 if the CEO is also the chairman of the board; founder is a binary variable that takes the value of 1 if the CEO is also the founder of the company. In Model 1b, we again find a significantly positive coefficient for the pay gap (5\% level). These results continue to hold in the matched sample (5\% level). Of note, we fail to find any association between 
founder status and duality with the likelihood of engaging in fraudulent behavior (in line with Feng et al., 2011 and Kryzanowski and Zhang, 2013). ${ }^{17}$

[Table 8 about here]

\subsection{Alternative fraud samples}

Karpoff et al. (2014) explore the advantages and disadvantages of the various databases used in fraud research. To test the robustness of our results, we examine whether the CEO pay gap is positively associated with the propensity to engage in fraudulent behavior in two alternative samples.

First, we use SEC Accounting and Auditing Enforcement Releases (AAERs), which are issued by the SEC during or at the conclusion of an investigation for alleged accounting and/or auditing misconduct. Hence, we set our dependent variable equal to 1 if the SEC published an AAER for the firm during the year, and 0 otherwise (Dechow et al., 2011).

Second, we use the likelihood of manipulation (F-score), obtained from Dechow et al. (2011). Our dependent variable takes a value of 0 if the F-score for a given observation is lower than 1 (indicating normal or low risk), a value of 1 if the F-score is greater than 1 but below 1.85 (indicating an above normal risk), a value of 2 if the F-score is greater than 1.85 but below 2.45 (indicating a substantial risk), and a value of 3 for an F-score greater than 2.45 (indicating a high risk) (Dechow et al., 2011; Jia, van Lent, and Zeng, 2014).

Our results with unchanged inferences are presented in Table 9. We find a significantly positive coefficient for both the F-score in the full sample (Model 1a), and for

\footnotetext{
${ }^{17}$ Feng et al. (2011) also include the CEO pay slice. Because this variable captures both tournament incentives and CEO power (CEO pay gap and slice are strongly correlated), we restrict our tabulated results to pure power measures (duality and founder status). However, our results are robust to including both the CEO pay slice and the CEO pay gap. We note that variance inflation factors are at conventionally low levels when including both.
} 
the AAERs in the full (Model 1b) and matched sample (Model 2b) at the 1 and 5\% level, respectively.

[Table 9 about here]

\section{Summary and implications}

Prior literature focused primarily on whether options and equity compensation provide incentives to commit fraud. This is of particular interest in the wake of the accounting scandals over the past decade. Given that fraud cases frequently involve non-CEO VPs and that prior literature documents these VPs respond to both equity-based and tournament incentives, we investigate a previously overlooked source of incentives potentially contributing to explain fraudulent behavior: tournament incentives.

Our results indicate that firms with larger tournament incentives, e.g., larger gaps between CEO and median VP pay, are more likely to engage in fraudulent activities. Therefore, similarly to equity-based compensation, the predicted alignment between shareholder and VP interests is not fully achieved. This result is robust to other research designs, other fraud samples, different measures of the pay gap, different measures of equitybased compensation, and controlling for corporate governance and CEO power

Our results are illustrative only for one aspect of tournament incentives, fraud, but they are consistent with other dysfunctional consequences of tournament incentives, such as sabotage and cheating, documented by prior literature. Other papers, however, have documented that tournament incentives can also lead to better cooperation and higher firm value (Kale, Reis, and Venkateswaran, 2009), and they can influence risk-taking (Kini and Williams, 2012). Hence, our results do not indicate whether the costs of tournament incentives generally outweigh the benefits, and they should be viewed as an indication that 
both equity-based and tournament incentives need to be considered (rather than being viewed strictly as evidence of the need to restrict CEO pay).

Our results have direct implications for the public debate on the structure of top executive compensation. Our findings can provide boards with an additional factor to take into account when assessing compensation programs and their incentive alignments. When large tournament incentives are present, corporate governance mechanisms aimed at monitoring could mitigate fraud by increasing the likelihood of detection. Accordingly, studying how the interaction of tournament incentives and monitoring mechanisms is associated with fraud is an interesting avenue for future research. Moreover, our study adds an extra dimension to the debate over outsize CEO compensation. While previous research focused on the effects of equity compensation with respect to fraud and the impact of tournament incentives on firm value, our findings indicate a dark side of tournament incentives. Finally, our findings have implications for the literature on fraud determinants by demonstrating the importance of the entire management team's pay, not just the CEO's pay. 


\section{References}

Aharony, J., Liu, C., and Yawson, A. 2015. Corporate litigation and executive turnover. Journal of Corporate Finance Forthcoming.

Alexander, C. R., and Cohen, M. A. 1999. Why do corporations become criminals? Ownership, hidden actions, and crime as an agency cost. Journal of Corporate Finance 5(1): 1-34.

Andersson, O., Holm, H.J., Tyran, J., and Wengström, E. 2013. Risking other people's money: experimental evidence on bonus schemes, competition, and altruism. Working paper available at SSRN 2466988.

Armstrong, C.S., Jagolinzer, A.D., and Larcker, D.F. 2010. Chief executive officer equity incentives and accounting irregularities. Journal of Accounting Research 48(2): 225271.

Armstrong, C.S., Larcker, D.F., Ormazabal, G., and Taylor, D.J. 2013. The relation between equity incentives and misreporting: the role of risk-taking incentives. Journal of Financial Economics 109(2): 327-350.

Baker, G.P. 1992. Incentive contracts and performance measurement. Journal of Political Economy 100(3): 598-614.

Baker, G.P., Jensen, M.C. and Murphy, K.J. 1988, Compensation and incentives: Practice versus theory. Journal of Finance 43(3): 593-616.

Ball, R. 2009. Market and political/regulatory perspectives on the recent accounting scandals. Journal of Accounting Research 47(2): 277-323.

Bebchuk, L.A., Cremers, K.J., and Peyer, U.C. 2011. The CEO pay slice. Journal of Financial Economics 102(1): 199-221.

Berentsen, A. 2002. The economics of doping. European Journal of Political Economy, 18(1): 109-127.

Berentsen, A., and Lengwiler, Y. 2004. Fraudulent accounting and other doping games. Journal of Institutional and Theoretical Economics, JITE 160(3): 402-415.

Bereskin, F. L., Campbell, T. L., and Kedia, S. 2014. Philanthropy, corporate culture and misconduct. Working paper available at SSRN 2370482.

Bergstresser, D., and Philippon, T. 2006. CEO incentives and earnings management. Journal of Financial Economics 80(3): 511-529.

Bhattacharya, U., and Marshall, C. D. 2012. Do they do it for the money?. Journal of Corporate Finance 18(1): 92-104. 
Black, F., and Scholes, M. 1973. The pricing of options and corporate liabilities. Journal of Political Economy 81(3): 637-654.

Bognanno, M.L. 2001. Corporate tournaments. Journal of Labor Economics 19(2): 290-315.

Brown, K.C., Harlow, W.V., Starks, L.T. 1996. Of tournaments and temptations: An analysis of managerial incentives in the mutual fund industry. Journal of Finance 51(1): 85110.

Burns, N., and Kedia, S. 2006. The impact of performance-based compensation on misreporting. Journal of Financial Economics 79(1): 35-67.

Chen, G., Firth, M., Gao, D. N., and Rui, O. M. 2006. Ownership structure, corporate governance, and fraud: Evidence from China. Journal of Corporate Finance, 12(3): 424-448.

Chen, J., Ezzamel, M., and Cai, Z. 2011. Managerial power theory, tournament theory, and executive pay in China. Journal of corporate finance 17(4): 1176-1199.

Cheng, I. H. 2011. Corporate governance spillovers. Working paper available at SSRN 1299652.

Chowdhury, S.M., and Gürtler, O. 2013. Sabotage in contests: A Survey. Working paper available at SSRN 2338077.

Conrads, J., Irlenbusch, B., Rilke, R. M., Schielke, A., and Walkowitz, G. 2014. Honesty in tournaments. Economics Letters 123(1): 90-93.

Core, J., and Guay, W. 2002. Estimating the value of employee stock option portfolios and their sensitivities to price and volatility. Journal of Accounting Research 40(3): 613630.

Cremers, K.J.M., and Grinstein, Y. 2014. Does the market for CEO talent explain controversial CEO pay practices? Review of Finance 1 18(3): 921-960.

Cumming, D., Leung, T., and Rui, O. 2015. Gender diversity and securities fraud. Academy of Management Journal amj-2013.

Dechenaux, E., Kovenock, D., and Sheremeta, R. M. 2014. A survey of experimental Research on contests, all-pay auctions and tournaments. Experimental Economics: Forthcoming.

Dechow, P. M., Ge, W., Larson, C. R., and Sloan, R. G. 2011. Predicting material accounting misstatements. Contemporary Accounting Research 28(1): 17-82.

Denis, D.J., Hanouna P., and Sarin A. 2006. Is there a dark side to incentive compensation? Journal of Corporate Finance 12(3): 467-488.

Drago, R. W., and Garvey, G. T. 1998. Incentives for helping on the job. Theory and 
evidence. Journal Labor Economics 16(1): 1-15.

Dyck, A., Morse, A., and Zingales, L. 2010. Who blows the whistle on corporate fraud? Journal of Finance 65(6): 2213-2253.

Efendi, J., Srivastava, A., and Swanson, E.P. 2007. Why do corporate managers misstate financial statements? The role of option compensation and other factors. Journal of Financial Economics 85(3): 667-708.

Ehrenberg, R., and Bognanno, M.L. 1990. The incentive effects of tournaments revisited: Evidence from the European PGA tour. Industrial \& Labor Relations Review 43(3): $74-89$.

Erickson, M., Hanlon, M., and Maydew, E.L. 2006. Is there a link between executive equity incentives and accounting fraud? Journal of Accounting Research 44(1): 113-143.

Faleye, O., Reis, E., and Venkateswaran, A. 2010. The effect of executive-employee pay disparity on labor productivity. Northeastern University Working Paper.

Feng, M., Ge, W., Luo, S., and Shevlin, T. 2011. Why do CFOs become involved in material accounting manipulations? Journal of Accounting and Economics 51(1): 21-36.

Firth, D. 1993. Bias reduction of maximum likelihood estimates. Biometrika, 80(1): 27-38.

Firth, M., Rui, O. M., and Wu, W. 2011. Cooking the books: Recipes and costs of falsified financial statements in China. Journal of Corporate Finance 17(2): 371-390.

Fuller, J., and Jensen, M.C., 2002. Just say no to Wall Street: Putting a stop to the earnings game. Journal of Applied Corporate Finance 14(4): 41-46.

Garicano, L., and Palacios-Huerta, I., 2006. Sabotage in tournaments: Making the beautiful game a bit less beautiful. Working paper available at SSRN 831964

Goel, A.M., and Thakor, A.V., 2008. Overconfidence, CEO selection, and corporate governance. The Journal of Finance 63(6): 2737-2784.

Goldman, E., and Slezak, S.L., 2006. An equilibrium model of incentive contracts in the presence of information manipulation. Journal of Financial Economics 80(3): 603626.

Gompers, P., Ishii, J., and Metrick, A., 2003. Corporate governance and equity prices. The Quarterly Journal of Economics 118(1): 107-156.

Gow, I. D., Ormazabal, G., and Taylor, D.J., 2010. Correcting for cross-sectional and time-series dependence in accounting research. The Accounting Review 85(2): 483512 .

Green, J. R., and Stokey, N. L., 1983. A comparison of tournaments and contracts, Journal of Political Economy 91(3): 349-364. 
Harbring, C., and Irlenbusch, B. 2011. Sabotage in tournaments: Evidence from a laboratory experiment. Management Science 57(4): 611-627.

Henderson, A.D., and Fredrickson, J.W., 2001. Top management team coordination needs the CEO pay gap: A competitive test of economic and behavioral views. Academy of Management Journal 44(1): 96-117.

Holmström, B., and Milgrom, P., 1991. Multitask principal-agent analyses: Incentive contracts, asset ownership, and job design. Journal of Law, Economics and Organization 7(SI): 24-52.

Jacob, B., and Levitt, S.D., 2003. Rotten apples: An investigation of the prevalence and predictors of teacher cheating. Quarterly Journal of Economics 118(3): 843-877.

Jayaraman, S., and Milbourn, T., 2014. CEO equity incentives and financial misreporting: The role of auditor expertise. The Accounting Review 90(1): 321-350.

Jensen, M.C., and Meckling, W.H., 1976. Theory of the firm: Managerial behavior, agency costs and ownership structure. Journal of Financial Economics 3(4): 305-360.

Jia, J., van Lent, L., and Zeng, Y., 2014. Masculinity, testosterone, and financial misreporting. Journal of Accounting Research 52(5): 1195-1246.

Jiang, J., Petroni, K.R., and Yanyan Wang, I., 2010. CFOs and CEOs: Who have the most influence on earnings management? Journal of Financial Economics 96(3): 513-526.

Johnson, M.F., Kasznik, R., and Nelson, K.K. 2000. Shareholder wealth effects of the private securities litigation reform act of 1995. Review of Accounting Studies 5(3): 217-233.

Kale, J.R., Reis, E., and Venkateswaran, A. 2009. Rank-order tournaments and incentive alignment: The effect on firm performance. Journal of Finance 64(3): 1479-1512.

Karpoff, J.M., Koester, A., Lee, D.S., and Martin, G.S. 2014. Database challenges in financial misconduct research. Georgetown McDonough School of Business Research Paper.

Karpoff, J.M., Lee, D.S., and Martin, G.S. 2008a. The cost to firms of cooking the books. Journal of Financial and Quantitative Analysis 43(3): 581-612.

Karpoff, J.M., Lee, D.S., and Martin, G.S. 2008b. The consequences to managers for financial misrepresentation. Journal of Financial Economics 88(2): 193-215.

Karpoff, J.M., and Lou, X., 2010. Short sellers and financial misconduct. Journal of Finance 65(5): 1879-1913.

Kedia, S., and Philippon, T. 2009. The economics of fraudulent accounting. Review of Financial Studies 22(6): 2169-2199. 
Kempf, A., and Ruenzi, S. (2008). Tournaments in mutual-fund families. Review of Financial Studies: 21(2): 1013-1036.

Kim, I., and Skinner, D.J. 2012. Measuring securities litigation risk. Journal of Accounting and Economics 53(1-2): 290-310.

Kini, O., and Williams, R. 2012. Tournament incentives, firm risk, and corporate policies. Journal of Financial Economics 103(2): 350-376.

Knoeber, C.R., and Thurman, W.N. 1994. Testing the theory of tournaments: An empirical analysis of broiler production. Journal of Labor Economics 12(2): 155-179.

Kräkel, M. 2007. Doping and cheating in contest-like situations. European Journal of Political Economy 23(4): 988-1006.

Kryzanowski, L., and Zhang, Y. 2013. Financial restatements and Sarbanes-Oxley: Impact on Canadian firm governance and management turnover. Journal of Corporate Finance 21: $87-105$.

Lazear, E.P. 1989. Pay equality and industrial politics. Journal of Political Economy 97(3): 561-580.

Lazear, E.P., and Rosen, S. 1981. Rank-order tournaments as optimum labor contracts. Journal of Political Economy 89(5): 841-864.

Lennox, C., and Pittman, J. A. 2010. Big five audits and accounting fraud. Contemporary Accounting Research 27(1): 209-247.

Li, Z. 2014. Mutual monitoring and corporate governance. Journal of Banking and Finance 45(SI): 255-269.

Lo, A. W., Wong, R. M., and Firth, M. 2010. Can corporate governance deter management from manipulating earnings? Evidence from related-party sales transactions in China. Journal of Corporate Finance 16(2): 225-235.

Masulis, R.W., and Zhang, S. 2012. Compensation gaps among top executives: Evidence of tournament incentives or productivity differentials? FIRN Research Paper.

Merton, R. 1973. Theory of rational option pricing. Bell Journal of Economics and Management Science 4(1): 141-183.

Mobbs, S., and Raheja, C. G. 2012. Internal managerial promotions: Insider incentives and CEO succession. Journal of Corporate Finance 18(5): 1337-1353.

Nalebuff, B.T., and Stiglitz, J.E. 1983. Prizes and incentives: Towards a general theory of compensation and competition. The Bell Journal of Economics 14(1): 21-43.

Peng, L., and Röell, A. 2008. Executive pay and shareholder litigation. Review of Finance 12(1): 141-184. 
Prendergast, C., 1999. The provision of incentives in firms. Journal of Economic Literature 37(1): 7-63.

Thompson, S.B., 2011. Simple formulas for standard errors that cluster by both firm and time. Journal of Financial Economics 99(1): 1-10.

Wang, T., 2004. Securities fraud: An economic analysis. University of Maryland Working Paper.

Wang, T.Y., and Winton, A., 2012. Competition and corporate fraud waves. Working paper available at SSRN 2103386. 


\section{Table 1}

Sample selection: This table summarizes our sample selection procedure. Our sample consists of 111 fraud firms where compensation data on ExecuComp were available. The initial sample consisted of 216 firms. The ExecuComp universe over the 1993-2003 period consists of 20,835 firm-years.

Fraud firms

Cases in DMZ (2010)

Multiple occurrences in the same year

Firm not in ExecuComp

Missing control variables

Non-fraud firms

ExecuComp universe 
Table 2

Sample distribution by year and industry: Frequency of fraud by year and industry. Our sample consists of 111 fraud firms where compensation data on ExecuComp was available.

\begin{tabular}{|c|c|}
\hline 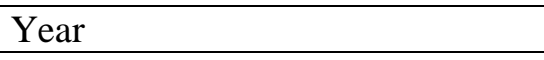 & $\%$ of fraud firms \\
\hline 1994 & $2.70 \%$ \\
\hline 1995 & $2.70 \%$ \\
\hline 1996 & $5.41 \%$ \\
\hline 1997 & $16.22 \%$ \\
\hline 1998 & $12.61 \%$ \\
\hline 1999 & $19.82 \%$ \\
\hline 2000 & $16.22 \%$ \\
\hline 2001 & $13.51 \%$ \\
\hline 2002 & $8.11 \%$ \\
\hline 2003 & $1.80 \%$ \\
\hline \multirow[t]{2}{*}{2004} & $0.90 \%$ \\
\hline & $100 \%$ \\
\hline Fama-French industry codes & $\%$ of fraud firms \\
\hline Food products & $2.70 \%$ \\
\hline Recreation & $0.90 \%$ \\
\hline Apparel & $0.90 \%$ \\
\hline Healthcare & $3.60 \%$ \\
\hline Medical equipment & $0.90 \%$ \\
\hline Pharmaceutical products & $5.41 \%$ \\
\hline Chemicals & $0.90 \%$ \\
\hline Textiles & $0.90 \%$ \\
\hline Construction & $1.80 \%$ \\
\hline Steel works & $0.90 \%$ \\
\hline Machinery & $1.80 \%$ \\
\hline Electrical equipment & $0.90 \%$ \\
\hline Aircraft & $1.80 \%$ \\
\hline Defense & $0.90 \%$ \\
\hline Precious metals & $0.90 \%$ \\
\hline Industrial metal mining & $0.90 \%$ \\
\hline Petroleum and natural gas & $1.80 \%$ \\
\hline Utilities & $9.91 \%$ \\
\hline Communication & $4.50 \%$ \\
\hline Personal services & $2.70 \%$ \\
\hline Business services & $9.91 \%$ \\
\hline Computers & $6.31 \%$ \\
\hline Electronic equipment & $4.50 \%$ \\
\hline Measuring and control equipment & $0.90 \%$ \\
\hline Transportation & $2.70 \%$ \\
\hline Wholesale & $5.41 \%$ \\
\hline Retail & $8.11 \%$ \\
\hline Banking & $9.01 \%$ \\
\hline Insurance & $6.31 \%$ \\
\hline \multirow[t]{2}{*}{ Other } & $1.80 \%$ \\
\hline & $100 \%$ \\
\hline
\end{tabular}


Table 3

Univariate comparison of the CEO pay gap and control variables among samples: Mean, median, standard deviation, upper and lower quartile for firm and compensation characteristics for the total sample, fraud and non-fraud firms. Our sample consists of 111 fraud firms that had compensation data on ExecuComp available. The non-fraud sample consists of the ExecuComp universe (fraud firms excluded). The matched sample consists of 111 non-fraud firms matched by size, industry, and year. Variables in dollar amounts are in thousands, except for total assets, which is in millions. All variables are winsorized at the 1\% and 99\% levels over the distribution of the full sample plus fraud firms, except for variables truncated at zero, which are winsorized at the $99 \%$ level. Statistical significance at the $10 \%, 5 \%$, and $1 \%$ levels is denoted by $* * *$, and ***, respectively. Variables are as defined in Appendices 1 and 2.

Panel A

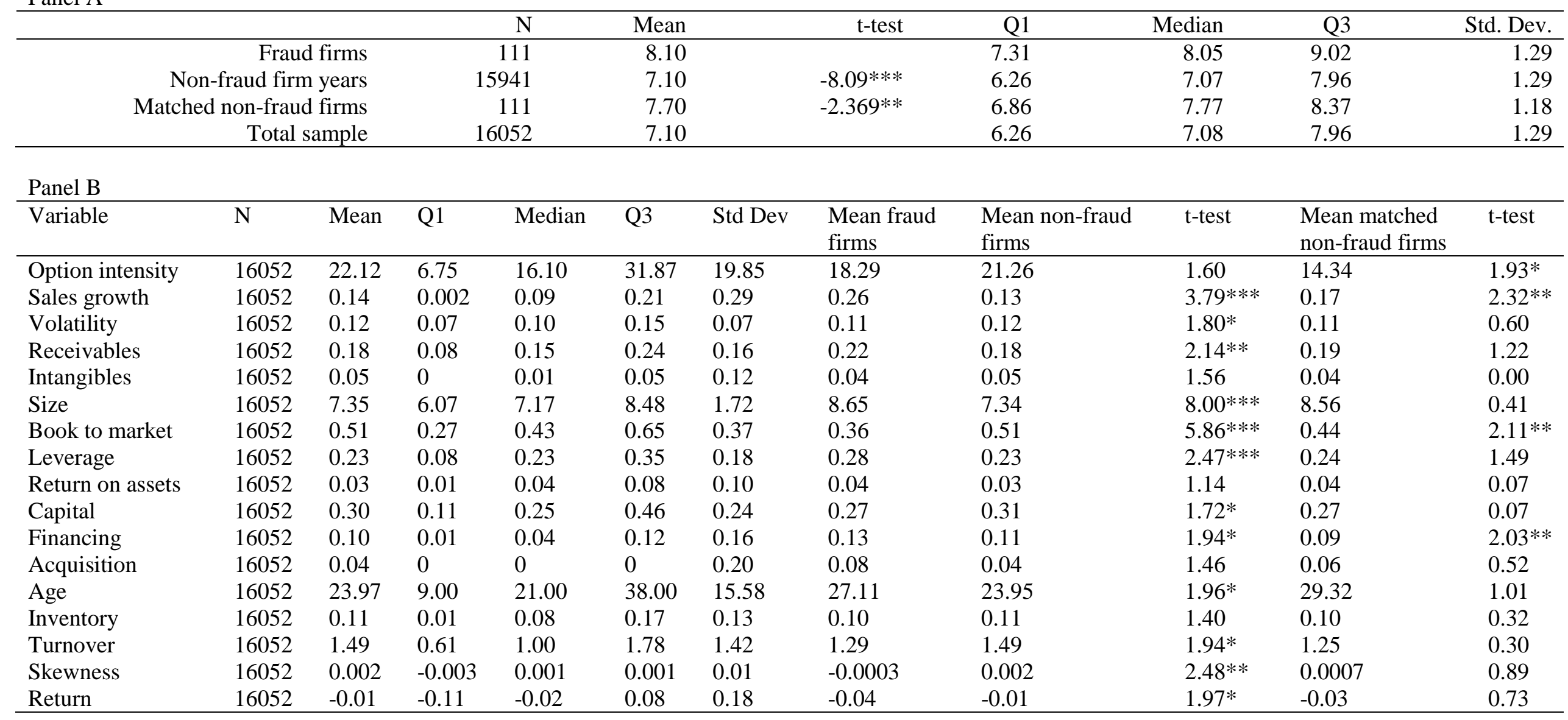




\section{Table 4}

Tournament incentives and corporate fraud. We perform a probit regression with a dummy variable equal to 1 for the first year the firm allegedly engaged in a fraud, and 0 otherwise. For Models 1 and 2, our sample consists of 111 fraud firms and all non-fraud firms in the ExecuComp universe. Standard errors are clustered by firm and year. For Model 3, our sample consists of 111 fraud firms and 111 non-fraud firms matched by size, industry, and year. Statistical significance at the $10 \%, 5 \%$, and $1 \%$ levels is denoted by *,**, and ***, respectively. Robust standard errors are reported in parentheses below the coefficients. Variables are as defined in Appendices 1 and 2.

\begin{tabular}{|c|c|c|c|}
\hline & Model 1 & Model 2 & Model 3 \\
\hline \multirow[t]{2}{*}{ CEO pay gap } & $0.2211 * * *$ & $0.1238 * * *$ & $0.1962 * *$ \\
\hline & $(0.0464)$ & $(0.0442)$ & $(0.0929)$ \\
\hline \multirow[t]{2}{*}{ Option intensity } & & 0.0018 & 0.0079 \\
\hline & & $(0.0021)$ & $(0.0065)$ \\
\hline \multirow[t]{2}{*}{ Sales growth } & & $0.3876 * * *$ & 0.4100 \\
\hline & & $(0.1008)$ & $(0.3336)$ \\
\hline \multirow[t]{2}{*}{ Volatility } & & 0.2810 & -2.7337 \\
\hline & & (1.0624) & (2.2699) \\
\hline \multirow[t]{2}{*}{ Receivables } & & 0.1551 & 0.8619 \\
\hline & & $(0.2115)$ & $(0.6514)$ \\
\hline \multirow[t]{2}{*}{ Intangibles } & & -0.4220 & -1.0163 \\
\hline & & $(0.8013)$ & $(1.3835)$ \\
\hline \multirow[t]{2}{*}{ Size } & & $0.1158 * * *$ & -0.0067 \\
\hline & & $(0.0307)$ & $(0.0890)$ \\
\hline \multirow[t]{2}{*}{ Book to market } & & $-0.5093 * * *$ & -0.2804 \\
\hline & & $(0.1621)$ & $(0.3174)$ \\
\hline \multirow[t]{2}{*}{ Leverage } & & -0.0008 & 0.3385 \\
\hline & & $(0.2174)$ & $(0.5817)$ \\
\hline \multirow[t]{2}{*}{ Return on assets } & & -0.2544 & -0.5588 \\
\hline & & $(0.6606)$ & (1.3115) \\
\hline \multirow[t]{2}{*}{ Capital } & & -0.0122 & 0.3738 \\
\hline & & $(0.1237)$ & $(0.5447)$ \\
\hline \multirow[t]{2}{*}{ Financing } & & $0.4948 * * *$ & 1.0591 \\
\hline & & $(0.1409)$ & $(0.7195)$ \\
\hline \multirow[t]{2}{*}{ Acquisition } & & -0.0245 & 0.0597 \\
\hline & & $(0.2118)$ & $(0.3785)$ \\
\hline \multirow[t]{2}{*}{ Age } & & 0.0004 & -0.0024 \\
\hline & & (0.0019) & $(0.0066)$ \\
\hline \multirow[t]{2}{*}{ Inventory } & & 0.1734 & 0.5276 \\
\hline & & $(0.2072)$ & $(0.7817)$ \\
\hline \multirow[t]{2}{*}{ Turnover } & & -0.0657 & 0.0246 \\
\hline & & $(0.0556)$ & (0.1095) \\
\hline \multirow[t]{2}{*}{ Skewness } & & $-9.6284 * *$ & -6.3868 \\
\hline & & (4.8217) & (11.6179) \\
\hline \multirow[t]{2}{*}{ Return } & & -0.2753 & -0.1989 \\
\hline & & $(0.1931)$ & $(0.5794)$ \\
\hline \multirow[t]{2}{*}{ Constant } & $-4.1302 * * *$ & $-4.2303 * * *$ & $-1.7384 *$ \\
\hline & $(0.3191)$ & $(0.3695)$ & $(0.9117)$ \\
\hline$N$ & 16052 & 16052 & 222 \\
\hline Log-Likelihood & -629.9650 & -597.2417 & -141.4497 \\
\hline
\end{tabular}




\section{Table 5}

Robustness tests: Alternative research designs. We perform a probit regression with a dummy variable equal to 1 for the first year the firm allegedly engaged in a fraud, and 0 otherwise. For Models 1 and 2, our sample consists of 111 fraud firms and all non-fraud firms in the ExecuComp universe. Model 1 is a probit regression including random effects (Lennox and Pittman, 2010). Model 2 is a logistic regression including industry fixed effects (Erickson, Hanlon, and Maydew, 2006). For Model 3, our sample consists of 111 fraud firms and 111 non-fraud firms matched by propensity score of being accused of fraud (Lennox and Pittman, 2010). Statistical significance at the 10\%, 5\%, and $1 \%$ levels is denoted by $*, * *$, and $* * *$, respectively. Standard errors are reported in parentheses below the coefficients. Variables are as defined in Appendices 1 and 2.

\begin{tabular}{|c|c|c|c|}
\hline & Model 1 & Model 2 & Model 3 \\
\hline \multirow[t]{2}{*}{ CEO pay gap } & $0.1238 * * *$ & $0.2892 * * *$ & $0.1771 *$ \\
\hline & $(0.0394)$ & $(0.1072)$ & $(0.0947)$ \\
\hline \multirow[t]{2}{*}{ Option intensity } & 0.0018 & 0.0091 & -0.0021 \\
\hline & $(0.0025)$ & $(0.0071)$ & $(0.0065)$ \\
\hline \multirow[t]{2}{*}{ Sales growth } & $0.3876^{* * *}$ & $0.9021 * * *$ & 0.3827 \\
\hline & $(0.1185)$ & $(0.3038)$ & $(0.3248)$ \\
\hline \multirow[t]{2}{*}{ Volatility } & 0.2810 & -0.2888 & -2.9658 \\
\hline & $(0.8395)$ & (2.3368) & $(2.2505)$ \\
\hline \multirow[t]{2}{*}{ Receivables } & 0.1551 & $2.2633 * *$ & -0.0525 \\
\hline & $(0.2577)$ & $(0.9379)$ & $(0.6530)$ \\
\hline \multirow[t]{2}{*}{ Intangibles } & -0.4220 & -1.2779 & 0.3135 \\
\hline & $(0.4924)$ & $(1.7671)$ & (1.5148) \\
\hline \multirow[t]{2}{*}{ Size } & $0.1158 * * *$ & $0.4422 * * *$ & -0.0621 \\
\hline & $(0.0349)$ & $(0.1059)$ & $(0.0889)$ \\
\hline \multirow[t]{2}{*}{ Book to market } & $-0.5093 * * *$ & $-1.6777 * * *$ & 0.2957 \\
\hline & $(0.1515)$ & $(0.4627)$ & $(0.4003)$ \\
\hline \multirow[t]{2}{*}{ Leverage } & -0.0008 & 0.5070 & 0.6875 \\
\hline & $(0.2359)$ & $(0.6947)$ & $(0.6121)$ \\
\hline \multirow[t]{2}{*}{ Return on assets } & -0.2544 & -0.6609 & -1.3521 \\
\hline & $(0.5239)$ & (1.4309) & (1.6294) \\
\hline \multirow[t]{2}{*}{ Capital } & -0.0122 & 0.0205 & -0.2789 \\
\hline & $(0.2096)$ & $(0.8100)$ & $(0.5934)$ \\
\hline \multirow[t]{2}{*}{ Financing } & $0.4948 * *$ & 0.9179 & 0.3712 \\
\hline & $(0.2302)$ & $(0.6326)$ & $(0.6722)$ \\
\hline \multirow[t]{2}{*}{ Acquisition } & -0.0245 & -0.0113 & -0.4906 \\
\hline & $(0.1582)$ & $(0.4071)$ & $(0.3282)$ \\
\hline \multirow[t]{2}{*}{ Age } & 0.0004 & -0.0060 & 0.0000 \\
\hline & $(0.0027)$ & $(0.0085)$ & $(0.0067)$ \\
\hline \multirow[t]{2}{*}{ Inventory } & 0.1734 & -0.0578 & -0.0557 \\
\hline & $(0.3252)$ & (1.2676) & $(0.7361)$ \\
\hline \multirow[t]{2}{*}{ Turnover } & -0.0657 & $-0.2264 *$ & 0.0111 \\
\hline & $(0.0412)$ & $(0.1184)$ & $(0.1034)$ \\
\hline \multirow[t]{2}{*}{ Skewness } & $-9.6283^{*}$ & $-26.7660^{*}$ & 3.1273 \\
\hline & (5.0400) & (13.7753) & (11.9736) \\
\hline \multirow[t]{2}{*}{ Return } & -0.2753 & -0.9716 & -0.1795 \\
\hline & $(0.2311)$ & $(0.6359)$ & $(0.5493)$ \\
\hline \multirow[t]{2}{*}{ Constant } & $-4.2303 * * *$ & $-13.0568 * * *$ & -0.7670 \\
\hline & $(0.3471)$ & $(1.2842)$ & $(0.9380)$ \\
\hline$N$ & 16052 & 16052 & 222 \\
\hline Log-Likelihood & -597.2417 & -561.2964 & -148.1308 \\
\hline
\end{tabular}




\section{Table 6}

Robustness tests: Pay gap as a measure of tournament incentives. We perform a probit regression with a dummy variable equal to 1 for the first year the firm allegedly engaged in a fraud and 0 otherwise. For Model 1a, our sample consists of 90 fraud firms and all non-fraud firms in the ExecuComp universe. For Model 1b, our sample consists of 104 fraud firms and all non-fraud firms in the ExecuComp universe. For Models 1c-e, our sample consists of 106 fraud firms and all non-fraud firms in the ExecuComp universe. Robust standard errors are clustered by firm and by year. For Model 2a, our sample consists of 90 fraud firms and 90 non-fraud firms matched by size, industry, and year. For Model $2 b$, our sample consists of 104 fraud firms and 104 non-fraud firms matched by size, industry, and year. For Models 2c-e, our sample consists of 106 fraud firms and 106 non-fraud firms matched by size, industry, and year. Statistical significance at the $10 \%$, 5\%, and $1 \%$ levels is denoted by $*, * *$, and $* * *$, respectively. Standard errors are reported in parentheses below the coefficients. Variables are as defined in Appendices 1 and 2 .

\begin{tabular}{|c|c|c|c|c|c|c|c|c|c|c|}
\hline & Model 1a & Model 1b & Model 1c & Model 1d & Model 1e & Model 2a & Model 2b & Model 2c & Model 2d & Model 2e \\
\hline CEO pay gap & & & $\begin{array}{c}0.1308 * * * \\
(0.0480)\end{array}$ & $\begin{array}{c}0.1341 * * * \\
(0.0470)\end{array}$ & $\begin{array}{c}0.1068 * * \\
(0.0477)\end{array}$ & & & $\begin{array}{c}0.2468 * * \\
(0.0976)\end{array}$ & $\begin{array}{c}0.2204 * * \\
(0.1100)\end{array}$ & $\begin{array}{c}0.2109 * * \\
(0.1028)\end{array}$ \\
\hline CEO pay gap (max VP) & $\begin{array}{c}0.0936 * * * \\
(0.0292)\end{array}$ & & & & & $\begin{array}{c}0.1979 * * \\
(0.0791)\end{array}$ & & & & \\
\hline CEO pay gap (mean VP) & & $\begin{array}{c}0.1062 * * \\
(0.0520)\end{array}$ & & & & & $\begin{array}{c}0.1759 * * \\
(0.0794)\end{array}$ & & & \\
\hline Average age & & & $\begin{array}{c}-0.0293 * * * \\
(0.0054)\end{array}$ & & & & & $\begin{array}{c}-0.0543 * * \\
(0.0229)\end{array}$ & & \\
\hline Pay growth $(\%)$ & & & & $\begin{array}{c}0.0000 \\
(0.0000)\end{array}$ & & & & & $\begin{array}{c}0.0000 \\
(0.0000)\end{array}$ & \\
\hline Pay growth & & & & & $\begin{array}{c}0.0000 * * * \\
(0.0000)\end{array}$ & & & & & $\begin{array}{c}0.0006 \\
(0.0007)\end{array}$ \\
\hline Option intensity & $\begin{array}{c}0.0033 \\
(0.0025)\end{array}$ & $\begin{array}{c}0.0034 \\
(0.0025)\end{array}$ & $\begin{array}{c}0.0021 \\
(0.0021)\end{array}$ & $\begin{array}{c}0.0024 \\
(0.0022)\end{array}$ & $\begin{array}{c}0.0024 \\
(0.0021)\end{array}$ & $\begin{array}{c}0.0098 \\
(0.0064)\end{array}$ & $\begin{array}{l}0.0148^{* *} \\
(0.0070)\end{array}$ & $\begin{array}{c}0.0095 \\
(0.0067)\end{array}$ & $\begin{array}{c}0.0101 \\
(0.0066)\end{array}$ & $\begin{array}{c}0.0105 \\
(0.0066)\end{array}$ \\
\hline Sales growth & $\begin{array}{c}0.3877 * * * \\
(0.0863)\end{array}$ & $\begin{array}{c}0.3281 * * * \\
(0.0738)\end{array}$ & $\begin{array}{l}0.3456^{* * * *} \\
(0.1020)\end{array}$ & $\begin{array}{l}0.3724^{\text {**** }} \\
(0.0919)\end{array}$ & $\begin{array}{l}0.3416^{* * * *} \\
(0.0793)\end{array}$ & $\begin{array}{c}0.7140 \\
(0.4506)\end{array}$ & $\begin{array}{c}0.4221 \\
(0.3844)\end{array}$ & $\begin{array}{c}0.3559 \\
(0.3606)\end{array}$ & $\begin{array}{c}0.2826 \\
(0.3834)\end{array}$ & $\begin{array}{c}0.2608 \\
(0.3770)\end{array}$ \\
\hline Volatility & $\begin{array}{c}1.0898 \\
(1.0928)\end{array}$ & $\begin{array}{c}0.3877 \\
(1.0655)\end{array}$ & $\begin{array}{l}-0.2585 \\
(1.0944)\end{array}$ & $\begin{array}{l}-0.1210 \\
(1.0858)\end{array}$ & $\begin{array}{l}-0.3180 \\
(1.0675)\end{array}$ & $\begin{array}{l}-2.8159 \\
(2.4254)\end{array}$ & $\begin{array}{l}-3.9032 \\
(2.3747)\end{array}$ & $\begin{array}{l}-2.6023 \\
(2.3773)\end{array}$ & $\begin{array}{l}-2.8746 \\
(2.3581)\end{array}$ & $\begin{array}{l}-2.9842 \\
(2.3835)\end{array}$ \\
\hline Receivables & $\begin{array}{c}0.0567 \\
(0.2789)\end{array}$ & $\begin{array}{c}0.2164 \\
(0.2205)\end{array}$ & $\begin{array}{c}0.1872 \\
(0.1991)\end{array}$ & $\begin{array}{c}0.1544 \\
(0.2034)\end{array}$ & $\begin{array}{c}0.1581 \\
(0.1969)\end{array}$ & $\begin{array}{c}0.7473 \\
(0.7207)\end{array}$ & $\begin{array}{c}1.0725 \\
(0.6754)\end{array}$ & $\begin{array}{c}0.8823 \\
(0.6717)\end{array}$ & $\begin{array}{c}0.9086 \\
(0.6703)\end{array}$ & $\begin{array}{c}0.9838 \\
(0.6772)\end{array}$ \\
\hline Intangibles & $\begin{array}{l}-1.3956 \\
(0.9738)\end{array}$ & $\begin{array}{l}-0.3201 \\
(0.8404)\end{array}$ & $\begin{array}{l}-0.3159 \\
(0.8324)\end{array}$ & $\begin{array}{l}-0.3342 \\
(0.8373)\end{array}$ & $\begin{array}{l}-0.3367 \\
(0.8497)\end{array}$ & $\begin{array}{l}-2.1446 \\
(2.3987)\end{array}$ & $\begin{array}{c}-0.0271 \\
(1.5980)\end{array}$ & $\begin{array}{l}-1.1719 \\
(1.4246)\end{array}$ & $\begin{array}{l}-1.0120 \\
(1.4083)\end{array}$ & $\begin{array}{l}-0.9190 \\
(1.4052)\end{array}$ \\
\hline
\end{tabular}


Table 6 (continued)

\begin{tabular}{|c|c|c|c|c|c|c|c|c|c|c|}
\hline Size & $\begin{array}{c}0.1374 * * * \\
(0.0341)\end{array}$ & $\begin{array}{c}0.1379 * * * \\
(0.0414)\end{array}$ & $\begin{array}{c}0.1203 * * * \\
(0.0320)\end{array}$ & $\begin{array}{c}0.1060 * * * \\
(0.0323)\end{array}$ & $\begin{array}{c}0.1051 * * * \\
(0.0325)\end{array}$ & $\begin{array}{l}-0.0078 \\
(0.0983)\end{array}$ & $\begin{array}{c}0.0363 \\
(0.0861)\end{array}$ & $\begin{array}{c}0.0309 \\
(0.0944)\end{array}$ & $\begin{array}{l}-0.0054 \\
(0.0922)\end{array}$ & $\begin{array}{l}-0.0003 \\
(0.0924)\end{array}$ \\
\hline Book to market & $\begin{array}{c}-0.5452 * * * \\
(0.1957)\end{array}$ & $\begin{array}{c}-0.4992 * * * \\
(0.1845)\end{array}$ & $\begin{array}{c}-0.4997 * * * \\
(0.1521)\end{array}$ & $\begin{array}{c}-0.4784 * * * \\
(0.1558)\end{array}$ & $\begin{array}{c}-0.4707 * * * \\
(0.1563)\end{array}$ & $\begin{array}{l}-0.3623 \\
(0.3220)\end{array}$ & $\begin{array}{l}-0.2325 \\
(0.3187)\end{array}$ & $\begin{array}{l}-0.3878 \\
(0.3339)\end{array}$ & $\begin{array}{l}-0.2222 \\
(0.3215)\end{array}$ & $\begin{array}{l}-0.2147 \\
(0.3234)\end{array}$ \\
\hline Leverage & $\begin{array}{l}-0.2201 \\
(0.2086)\end{array}$ & $\begin{array}{c}-0.0609 \\
(0.2178)\end{array}$ & $\begin{array}{l}-0.0321 \\
(0.2215)\end{array}$ & $\begin{array}{c}0.0218 \\
(0.2284)\end{array}$ & $\begin{array}{c}0.0368 \\
(0.2303)\end{array}$ & $\begin{array}{c}0.0821 \\
(0.6685)\end{array}$ & $\begin{array}{c}0.0724 \\
(0.6028)\end{array}$ & $\begin{array}{c}0.2485 \\
(0.6046)\end{array}$ & $\begin{array}{c}0.3384 \\
(0.5995)\end{array}$ & $\begin{array}{c}0.3804 \\
(0.6048)\end{array}$ \\
\hline Return on assets & $\begin{array}{l}-0.0050 \\
(0.6576)\end{array}$ & $\begin{array}{l}-0.1802 \\
(0.5973)\end{array}$ & $\begin{array}{l}-0.2871 \\
(0.6373)\end{array}$ & $\begin{array}{c}-0.3157 \\
(0.6388)\end{array}$ & $\begin{array}{l}-0.3615 \\
(0.6358)\end{array}$ & $\begin{array}{l}-0.4197 \\
(1.4810)\end{array}$ & $\begin{array}{l}-0.2844 \\
(1.4214)\end{array}$ & $\begin{array}{l}-0.5923 \\
(1.3522)\end{array}$ & $\begin{array}{l}-0.6090 \\
(1.3540)\end{array}$ & $\begin{array}{l}-0.4885 \\
(1.3643)\end{array}$ \\
\hline Capital & $\begin{array}{c}-0.1068 \\
(0.1615)\end{array}$ & $\begin{array}{c}0.0228 \\
(0.1502)\end{array}$ & $\begin{array}{c}0.0114 \\
(0.1317)\end{array}$ & $\begin{array}{l}-0.0269 \\
(0.1351)\end{array}$ & $\begin{array}{l}-0.0214 \\
(0.1354)\end{array}$ & $\begin{array}{c}0.0008 \\
(0.6160)\end{array}$ & $\begin{array}{c}0.4270 \\
(0.5625)\end{array}$ & $\begin{array}{c}0.5273 \\
(0.5642)\end{array}$ & $\begin{array}{c}0.4888 \\
(0.5579)\end{array}$ & $\begin{array}{c}0.5376 \\
(0.5625)\end{array}$ \\
\hline Financing & $\begin{array}{c}0.4439 * * * \\
(0.1625)\end{array}$ & $\begin{array}{c}0.4473 * * * \\
(0.1251)\end{array}$ & $\begin{array}{c}0.4337 * * \\
(0.1775)\end{array}$ & $\begin{array}{l}0.4423^{* *} \\
(0.1754)\end{array}$ & $\begin{array}{c}0.4428 * * \\
(0.1794)\end{array}$ & $\begin{array}{c}0.5111 \\
(0.7822)\end{array}$ & $\begin{array}{c}0.8204 \\
(0.7678)\end{array}$ & $\begin{array}{c}0.8013 \\
(0.7797)\end{array}$ & $\begin{array}{c}0.8439 \\
(0.7738)\end{array}$ & $\begin{array}{c}0.7205 \\
(0.8098)\end{array}$ \\
\hline Acquisition & $\begin{array}{l}-0.0134 \\
(0.2000)\end{array}$ & $\begin{array}{c}0.0651 \\
(0.2009)\end{array}$ & $\begin{array}{c}0.0205 \\
(0.2107)\end{array}$ & $\begin{array}{c}0.0065 \\
(0.2133)\end{array}$ & $\begin{array}{c}0.0001 \\
(0.2170)\end{array}$ & $\begin{array}{l}-0.4061 \\
(0.4187)\end{array}$ & $\begin{array}{c}0.0539 \\
(0.3890)\end{array}$ & $\begin{array}{c}0.2101 \\
(0.3987)\end{array}$ & $\begin{array}{c}0.2101 \\
(0.3985)\end{array}$ & $\begin{array}{c}0.2577 \\
(0.4004)\end{array}$ \\
\hline Age & $\begin{array}{c}0.0015 \\
(0.0028)\end{array}$ & $\begin{array}{c}0.0020 \\
(0.0022)\end{array}$ & $\begin{array}{c}0.0014 \\
(0.0020)\end{array}$ & $\begin{array}{c}0.0004 \\
(0.0021)\end{array}$ & $\begin{array}{c}0.0005 \\
(0.0021)\end{array}$ & $\begin{array}{l}-0.0002 \\
(0.0075)\end{array}$ & $\begin{array}{l}-0.0002 \\
(0.0069)\end{array}$ & $\begin{array}{l}-0.0015 \\
(0.0069)\end{array}$ & $\begin{array}{l}-0.0032 \\
(0.0069)\end{array}$ & $\begin{array}{l}-0.0035 \\
(0.0069)\end{array}$ \\
\hline Inventory & $\begin{array}{l}0.4249 * * \\
(0.1987)\end{array}$ & $\begin{array}{c}0.2789 \\
(0.1868)\end{array}$ & $\begin{array}{c}0.2626 \\
(0.1932)\end{array}$ & $\begin{array}{c}0.1914 \\
(0.2015)\end{array}$ & $\begin{array}{c}0.2117 \\
(0.1997)\end{array}$ & $\begin{array}{c}0.5376 \\
(0.8455)\end{array}$ & $\begin{array}{c}0.7263 \\
(0.8242)\end{array}$ & $\begin{array}{c}0.4941 \\
(0.8075)\end{array}$ & $\begin{array}{c}0.5404 \\
(0.8022)\end{array}$ & $\begin{array}{c}0.6397 \\
(0.8151)\end{array}$ \\
\hline Turnover & $\begin{array}{l}-0.0703 \\
(0.0631)\end{array}$ & $\begin{array}{l}-0.0618 \\
(0.0627)\end{array}$ & $\begin{array}{l}-0.0792 \\
(0.0604)\end{array}$ & $\begin{array}{l}-0.0663 \\
(0.0590)\end{array}$ & $\begin{array}{l}-0.0642 \\
(0.0578)\end{array}$ & $\begin{array}{c}0.0188 \\
(0.1201)\end{array}$ & $\begin{array}{l}-0.0064 \\
(0.1149)\end{array}$ & $\begin{array}{l}-0.0123 \\
(0.1235)\end{array}$ & $\begin{array}{c}0.0439 \\
(0.1209)\end{array}$ & $\begin{array}{c}0.0353 \\
(0.1218)\end{array}$ \\
\hline Skewness & $\begin{array}{c}-10.0532 * \\
(5.7495)\end{array}$ & $\begin{array}{l}-8.4421 * \\
(4.9250)\end{array}$ & $\begin{array}{l}-7.6870 * \\
(4.5070)\end{array}$ & $\begin{array}{l}-7.5325 * \\
(4.3753)\end{array}$ & $\begin{array}{l}-7.0625 \\
(4.5724)\end{array}$ & $\begin{array}{c}-0.1250 \\
(13.4487)\end{array}$ & $\begin{array}{c}6.4229 \\
(12.4429)\end{array}$ & $\begin{array}{c}-8.7884 \\
(12.4673)\end{array}$ & $\begin{array}{c}-5.2146 \\
(12.2279)\end{array}$ & $\begin{array}{c}-6.4001 \\
(12.2696)\end{array}$ \\
\hline Return & $\begin{array}{c}-0.3164 \\
(0.2183)\end{array}$ & $\begin{array}{c}-0.4074 * \\
(0.2236)\end{array}$ & $\begin{array}{l}-0.2306 \\
(0.1936)\end{array}$ & $\begin{array}{c}-0.2260 \\
(0.1885)\end{array}$ & $\begin{array}{c}-0.2598 \\
(0.1904)\end{array}$ & $\begin{array}{l}-0.0955 \\
(0.6388)\end{array}$ & $\begin{array}{l}-0.6252 \\
(0.6071)\end{array}$ & $\begin{array}{c}0.1156 \\
(0.6195)\end{array}$ & $\begin{array}{l}-0.0611 \\
(0.6161)\end{array}$ & $\begin{array}{l}-0.1241 \\
(0.6407)\end{array}$ \\
\hline Constant & $\begin{array}{c}-4.1842 * * * \\
(0.3673)\end{array}$ & $\begin{array}{c}-4.4057 * * * \\
(0.3656)\end{array}$ & $\begin{array}{c}-2.8119 * * * \\
(0.4664)\end{array}$ & $\begin{array}{c}-4.1993 * * * \\
(0.4066)\end{array}$ & $\begin{array}{c}-3.9878 * * * \\
(0.4096)\end{array}$ & $\begin{array}{l}-1.4537 \\
(0.9706)\end{array}$ & $\begin{array}{c}-2.0082 * * \\
(0.9654) \\
\end{array}$ & $\begin{array}{l}0.3212 \\
1.3805 \\
\end{array}$ & $\begin{array}{c}-1.9997 * * \\
(0.9664) \\
\end{array}$ & $\begin{array}{c}-2.0187 * * \\
(0.9292)\end{array}$ \\
\hline $\begin{array}{l}N \\
\text { Log-Likelihood }\end{array}$ & $\begin{array}{c}13473 \\
-487.0062\end{array}$ & $\begin{array}{c}15624 \\
-561.8550\end{array}$ & $\begin{array}{c}14881 \\
-564.2927\end{array}$ & $\begin{array}{c}14881 \\
-569.4333\end{array}$ & $\begin{array}{c}14881 \\
-566.2362\end{array}$ & $\begin{array}{c}180 \\
-112.8513\end{array}$ & $\begin{array}{c}208 \\
-130.5900\end{array}$ & $\begin{array}{c}212 \\
-130.8637\end{array}$ & $\begin{array}{c}212 \\
-133.6445\end{array}$ & $\begin{array}{c}212 \\
-133.2810\end{array}$ \\
\hline
\end{tabular}




\section{Table 7}

Robustness tests: Alternative measures for equity-based incentives. We perform a probit regression with a dummy variable equal to 1 for the first year the firm allegedly engaged in a fraud, and 0 otherwise. For Model 1a, our sample consists of 104 fraud firms and all non-fraud firms in the ExecuComp universe. Standard errors are clustered by firm and by year. For Model 1b, our sample consists of 53 fraud firms and all non-fraud firms in the ExecuComp universe. Robust standard errors are clustered by firm and by year. For Model 2a, our sample consists of 98 fraud firms and 98 nonfraud firms matched by size, industry, and, year. Statistical significance at the $10 \%, 5 \%$, and $1 \%$ levels is denoted by $*, * *$, and $* * *$, respectively. Standard errors are reported in parentheses below the coefficients. Variables are as defined in Appendices 1 and 2.

\begin{tabular}{|c|c|c|c|}
\hline & Model 1a & Model 2a & Model 1b \\
\hline \multirow[t]{2}{*}{ CEO pay gap } & $0.1101 * * *$ & 0.1647 & $0.0927 * *$ \\
\hline & $(0.0415)$ & $(0.1091)$ & $(0.0394)$ \\
\hline \multirow[t]{2}{*}{ Delta CEO } & 0.0117 & 0.2202 & -0.0145 \\
\hline & $(0.0449)$ & $(0.1541)$ & $(0.0445)$ \\
\hline \multirow[t]{2}{*}{ Vega CEO } & -0.0272 & 0.0048 & $0.2422 * * *$ \\
\hline & $(0.0765)$ & $(0.1511)$ & $(0.0822)$ \\
\hline \multirow[t]{2}{*}{ Delta VPs } & 0.0505 & -0.2410 & \\
\hline & $(0.0784)$ & $(0.2442)$ & \\
\hline \multirow[t]{2}{*}{ Vega VPs } & 0.0873 & 0.1467 & \\
\hline & $(0.1064)$ & $(0.2277)$ & \\
\hline Delta CFO & & & $\begin{array}{c}0.1662 * * * \\
(0.0310)\end{array}$ \\
\hline \multirow[t]{2}{*}{ Vega CFO } & & & -0.1141 \\
\hline & & & $(0.1064)$ \\
\hline \multirow[t]{2}{*}{ Sales growth } & $0.3287 * * *$ & 0.6306 & $0.3336^{*}$ \\
\hline & $(0.0928)$ & $(0.4293)$ & $(0.1710)$ \\
\hline \multirow[t]{2}{*}{ Volatility } & 0.3995 & -2.4083 & -0.2255 \\
\hline & (1.1799) & $(2.4468)$ & (1.6865) \\
\hline \multirow[t]{2}{*}{ Receivables } & $0.3543 *$ & 0.7081 & $0.3655^{* *}$ \\
\hline & (0.1969) & $(0.7037)$ & $(0.1835)$ \\
\hline \multirow[t]{2}{*}{ Intangibles } & -0.5898 & -1.4930 & 0.4316 \\
\hline & $(0.8225)$ & (1.4237) & $(0.8651)$ \\
\hline \multirow[t]{2}{*}{ Size } & 0.0532 & -0.0869 & 0.0340 \\
\hline & $(0.0371)$ & (0.0999) & $(0.0419)$ \\
\hline \multirow[t]{2}{*}{ Book to market } & $-0.4127 *$ & -0.1541 & -0.4482 \\
\hline & $(0.2177)$ & $(0.3735)$ & $(0.3166)$ \\
\hline \multirow[t]{2}{*}{ Leverage } & 0.0702 & 0.3752 & $0.7399 * * *$ \\
\hline & $(0.2743)$ & $(0.6332)$ & $(0.2262)$ \\
\hline \multirow[t]{2}{*}{ Return on assets } & -0.6270 & -1.2020 & -0.2321 \\
\hline & $(0.6581)$ & (1.4068) & $(0.4073)$ \\
\hline \multirow[t]{2}{*}{ Capital } & 0.0464 & -0.0182 & 0.1122 \\
\hline & $(0.1330)$ & $(0.5759)$ & $(0.2342)$ \\
\hline \multirow[t]{2}{*}{ Financing } & $0.4884 * * *$ & $1.4864^{*}$ & 0.1203 \\
\hline & $(0.1547)$ & $(0.8174)$ & $(0.3900)$ \\
\hline \multirow[t]{2}{*}{ Acquisition } & 0.0219 & -0.0224 & -0.2307 \\
\hline & $(0.2021)$ & $(0.4085)$ & $(0.2300)$ \\
\hline \multirow[t]{2}{*}{ Age } & 0.0007 & 0.0002 & 0.0006 \\
\hline & $(0.0025)$ & $(0.0074)$ & $(0.0023)$ \\
\hline \multirow[t]{2}{*}{ Inventory } & 0.1411 & 0.2777 & 0.4304 \\
\hline & $(0.2417)$ & $(0.8661)$ & $(0.4231)$ \\
\hline
\end{tabular}


Table 7 (continued)

\begin{tabular}{lccc} 
Turnover & -0.0885 & -0.0707 & $-0.1208^{* * *}$ \\
& $(0.0543)$ & $(0.1438)$ & $(0.0461)$ \\
Skewness & $-10.5061^{*}$ & -10.7458 & $-12.8446^{* *}$ \\
& $(5.4968)$ & $(12.6296)$ & $(5.3574)$ \\
Return & -0.2513 & -0.3584 & -0.5278 \\
& $(0.2301)$ & $(0.6248)$ & $(0.4083)$ \\
Constant & $-4.1145^{* * *}$ & -1.2829 & $-4.6396 * *$ \\
& $(0.3999)$ & $(1.0226)$ & $(0.5167)$ \\
\hline$N$ & 15089 & 196 & 5386 \\
Log-Likelihood & -557.1443 & -122.3508 & -245.6425 \\
\hline
\end{tabular}




\section{Table 8}

Robustness tests: Corporate governance and CEO power. We perform a probit regression with a dummy variable equal to 1 for the first year the firm allegedly engaged in a fraud, and 0 otherwise. For Model 1a, our sample consists of 68 fraud firms and all non-fraud firms in the ExecuComp universe. Standard errors are clustered by firm and by year. For Model 2a, our sample consists of 68 fraud firms and 68 non-fraud firms matched by size, industry and year. For Models $1 \mathrm{~b}$ and 1c, our sample consists of 110 fraud firms and all non-fraud firms in the ExecuComp universe. For Model 1d, our sample consists of 111 fraud firms and all non-fraud firms in the ExecuComp universe. Robust standard errors are clustered by firm and by year. For Model 2b, our sample consists of 110 fraud firms and 110 nonfraud firms matched by size, industry, and year. Statistical significance at the $10 \%, 5 \%$, and $1 \%$ levels is denoted by $*, * *$, and $* * *$, respectively. Standard errors are reported in parentheses below the coefficients. Variables are as defined in Appendices 1 and 2.

\begin{tabular}{|c|c|c|c|c|c|c|}
\hline & Model 1a & Model 2a & Model 1b & Model 1c & Model 1d & Model 2b \\
\hline \multirow[t]{2}{*}{ CEO pay gap } & $0.1367 * *$ & 0.1662 & $0.1171 * *$ & $0.1159 * *$ & $0.1259 * * *$ & $0.2251 * *$ \\
\hline & $(0.0569)$ & $(0.1402)$ & $(0.0469)$ & $(0.0473)$ & $(0.0430)$ & $(0.0952)$ \\
\hline \multirow[t]{2}{*}{ Independence } & 0.2873 & 1.0212 & & & & \\
\hline & $(0.2077)$ & $(0.8010)$ & & & & \\
\hline \multirow[t]{2}{*}{ Classified board } & 0.0058 & 0.1777 & & & & \\
\hline & $(0.0775)$ & $(0.2862)$ & & & & \\
\hline \multirow[t]{2}{*}{ G index } & 0.0047 & -0.0860 & & & & \\
\hline & $(0.0272)$ & $(0.0616)$ & & & & \\
\hline \multirow[t]{2}{*}{ Founder } & & & 0.0599 & & 0.0420 & 0.1319 \\
\hline & & & $(0.1333)$ & & $(0.1255)$ & $(0.2579)$ \\
\hline \multirow[t]{2}{*}{ Duality } & & & 0.0972 & 0.0916 & & -0.2496 \\
\hline & & & $(0.3928)$ & $(0.3963)$ & & $(0.2175)$ \\
\hline \multirow[t]{2}{*}{ Option intensity } & 0.0040 & 0.0135 & 0.0019 & 0.0020 & 0.0014 & 0.0088 \\
\hline & $(0.0029)$ & $(0.0099)$ & $(0.0024)$ & $(0.0024)$ & $(0.0023)$ & $(0.0065)$ \\
\hline \multirow[t]{2}{*}{ Sales growth } & $0.5535^{* * * *}$ & 0.6278 & $0.3735^{* * *}$ & $0.3733 * * *$ & $0.3878 * * *$ & 0.3415 \\
\hline & $(0.1553)$ & $(0.4391)$ & $(0.0969)$ & $(0.0977)$ & $(0.1001)$ & $(0.3394)$ \\
\hline \multirow[t]{2}{*}{ Volatility } & 0.7719 & -4.9743 & 0.6561 & 0.6529 & 0.2980 & -3.1220 \\
\hline & (1.4944) & $(3.0870)$ & $(1.1460)$ & $(1.1521)$ & $(1.0503)$ & $(2.3002)$ \\
\hline \multirow[t]{2}{*}{ Receivables } & 0.2965 & 0.7097 & 0.2099 & 0.2073 & 0.1544 & 0.8205 \\
\hline & $(0.3280)$ & $(0.8509)$ & $(0.2218)$ & $(0.2200)$ & $(0.2117)$ & $(0.6539)$ \\
\hline \multirow[t]{2}{*}{ Intangibles } & 0.1944 & 0.1235 & -0.6507 & -0.6456 & -0.4284 & -1.1472 \\
\hline & $(1.0430)$ & $(2.3075)$ & $(0.8039)$ & $(0.8036)$ & $(0.7995)$ & $(1.4063)$ \\
\hline \multirow[t]{2}{*}{ Size } & $0.1453^{* * *}$ & 0.0255 & $0.1161 * * *$ & $0.1178 * * *$ & $0.1123 * * *$ & -0.0059 \\
\hline & $(0.0288)$ & $(0.1350)$ & $(0.0331)$ & $(0.0327)$ & $(0.0310)$ & $(0.0894)$ \\
\hline \multirow[t]{2}{*}{ Book to market } & $-0.6738^{* * *}$ & -0.5346 & $-0.6903 * * *$ & $-0.6930 * * *$ & $-0.5077 * * *$ & -0.3107 \\
\hline & $(0.1775)$ & $(0.4714)$ & $(0.2190)$ & $(0.2182)$ & $(0.1623)$ & $(0.3227)$ \\
\hline \multirow[t]{2}{*}{ Leverage } & 0.0987 & -0.1837 & 0.0021 & -0.0023 & 0.0092 & 0.4239 \\
\hline & $(0.3483)$ & $(0.8365)$ & $(0.2914)$ & $(0.2891)$ & $(0.2223)$ & $(0.5883)$ \\
\hline \multirow[t]{2}{*}{ Return on assets } & -0.3925 & -0.6833 & -0.7211 & -0.7006 & -0.2714 & -0.6388 \\
\hline & (1.0706) & $(1.6340)$ & $(0.6905)$ & $(0.7051)$ & $(0.6419)$ & (1.3243) \\
\hline \multirow[t]{2}{*}{ Capital } & 0.1816 & 0.5703 & 0.0242 & 0.0261 & -0.0197 & 0.4668 \\
\hline & $(0.2525)$ & $(0.7821)$ & $(0.1265)$ & $(0.1268)$ & $(0.1230)$ & $(0.5499)$ \\
\hline \multirow[t]{2}{*}{ Financing } & 0.2439 & 1.5536 & $0.5337 * * *$ & $0.5313 * * *$ & $0.4972 * * *$ & 0.9751 \\
\hline & $(0.2591)$ & (1.1809) & $(0.1977)$ & $(0.1996)$ & $(0.1402)$ & $(0.7295)$ \\
\hline \multirow[t]{2}{*}{ Acquisition } & -0.2524 & -0.4434 & -0.0250 & -0.0234 & -0.0262 & 0.1024 \\
\hline & $(0.2350)$ & $(0.6668)$ & $(0.2165)$ & $(0.2212)$ & $(0.2074)$ & $(0.3817)$ \\
\hline \multirow[t]{2}{*}{ Age } & 0.0010 & -0.0025 & 0.0007 & 0.0000 & 0.0007 & -0.0008 \\
\hline & $(0.0024)$ & $(0.0104)$ & $(0.0030)$ & $(0.0024)$ & $(0.0023)$ & $(0.0074)$ \\
\hline \multirow[t]{2}{*}{ Inventory } & $0.7368^{* *}$ & 0.9322 & 0.2199 & 0.2231 & 0.1668 & 0.5354 \\
\hline & $(0.3202)$ & $(1.1424)$ & $(0.2479)$ & $(0.2520)$ & $(0.2057)$ & $(0.8112)$ \\
\hline
\end{tabular}


Table 8 (continued)

\begin{tabular}{lcccccc} 
Turnover & -0.0585 & 0.0854 & -0.0747 & -0.0743 & -0.0658 & 0.0653 \\
& $(0.0719)$ & $(0.1634)$ & $(0.0601)$ & $(0.0607)$ & $(0.0550)$ & $(0.1151)$ \\
Skewness & $-17.3170^{* *}$ & -16.6464 & $-11.0720^{*}$ & $-11.0195^{*}$ & $-9.6376^{* *}$ & -9.9718 \\
& $(8.3493)$ & $(15.1777)$ & $(5.7032)$ & $(5.7301)$ & $(4.7853)$ & $(13.1107)$ \\
\multirow{2}{*}{ Return } & -0.3251 & -0.1586 & -0.2696 & -0.2693 & -0.2761 & -0.0371 \\
& $(0.2806)$ & $(0.7766)$ & $(0.2208)$ & $(0.2207)$ & $(0.1931)$ & $(0.6298)$ \\
Constant & $-5.1945^{* * *}$ & -1.5967 & $-4.1456^{* * *}$ & $-4.1220^{* * *}$ & $-4.2296^{* * *}$ & $-4.3890^{* * *}$ \\
& $(0.6619)$ & $(1.6314)$ & $(0.3808)$ & $(0.3874)$ & $(0.3572)$ & $(1.0880)$ \\
\hline$N$ & 8210 & 138 & 14627 & 14627 & 16051 & 220 \\
Log-Likelihood & -343.8786 & -83.4185 & -552.2309 & -552.4092 & -597.2297 & -139.0648 \\
\hline
\end{tabular}


Table 9

Robustness tests: Alternative fraud samples. We perform a probit regression with a dummy variable equal to 1 for the first year the firm engaged in a fraud, and 0 otherwise. For Model 1a, we use the Fscore developed by Dechow et al. (2011). For Model 1b, our sample consists of 351 AAER firms and all non-fraud firms in the ExecuComp universe. Robust standard errors are clustered by firm and by year. For Model 2b, our sample consists of 334 AAER firms and 334 non-AAER firms matched by size, industry, and year. Statistical significance at the $10 \%, 5 \%$, and $1 \%$ levels is denoted by *,**, and ***, respectively. Standard errors are reported in parentheses below the coefficients. Variables are as defined in Appendices 1 and 2.

\begin{tabular}{|c|c|c|c|}
\hline & Model 1a & Model 1b & Model 2b \\
\hline \multirow[t]{2}{*}{ CEO pay gap } & $0.0814 * * *$ & $0.1266 * * *$ & $0.1181 * *$ \\
\hline & $(0.0198)$ & $(0.0300)$ & $(0.0499)$ \\
\hline \multirow[t]{2}{*}{ Option intensity } & $-0.0033 * *$ & $0.0046^{* *}$ & $0.0087 * * *$ \\
\hline & $(0.0014)$ & $(0.0021)$ & $(0.0033)$ \\
\hline \multirow[t]{2}{*}{ Sales growth } & $0.5524 * * *$ & $0.1876^{* *}$ & 0.2244 \\
\hline & $(0.0655)$ & $(0.0740)$ & $(0.1671)$ \\
\hline \multirow[t]{2}{*}{ Volatility } & -0.1298 & 0.8451 & $-2.0290 * *$ \\
\hline & $(0.3315)$ & $(0.6149)$ & $(1.0067)$ \\
\hline \multirow[t]{2}{*}{ Receivables } & $-0.5532 * * *$ & -0.2593 & 0.1390 \\
\hline & $(0.1696)$ & $(0.2669)$ & $(0.3996)$ \\
\hline \multirow[t]{2}{*}{ Intangibles } & $-1.0213 * * *$ & -0.4084 & $-1.0716^{*}$ \\
\hline & $(0.2430)$ & $(0.3865)$ & $(0.6394)$ \\
\hline \multirow[t]{2}{*}{ Size } & $-0.1537 * * *$ & $0.0966 * * *$ & 0.0010 \\
\hline & $(0.0240)$ & $(0.0247)$ & $(0.0493)$ \\
\hline \multirow[t]{2}{*}{ Book to market } & 0.0529 & -0.0784 & 0.1046 \\
\hline & $(0.0737)$ & (0.1109) & $(0.1551)$ \\
\hline \multirow[t]{2}{*}{ Leverage } & $1.3603 * * *$ & 0.2977 & $0.7535^{* *}$ \\
\hline & $(0.1563)$ & $(0.2470)$ & $(0.3420)$ \\
\hline \multirow[t]{2}{*}{ Return on assets } & $1.4589 * * *$ & 0.2330 & -0.4386 \\
\hline & $(0.1714)$ & $(0.3223)$ & $(0.6473)$ \\
\hline \multirow[t]{2}{*}{ Capital } & $-2.8274 * * *$ & $-0.5902 * * *$ & -0.3275 \\
\hline & $(0.1412)$ & $(0.2134)$ & $(0.3154)$ \\
\hline \multirow[t]{2}{*}{ Financing } & $1.5452 * * *$ & -0.0904 & -0.1473 \\
\hline & $(0.1632)$ & $(0.1882)$ & $(0.3955)$ \\
\hline \multirow[t]{2}{*}{ Acquisition } & $0.4286 * * *$ & $0.1911 * * *$ & 0.1599 \\
\hline & $(0.0720)$ & $(0.0653)$ & $(0.2108)$ \\
\hline \multirow[t]{2}{*}{ Age } & $0.0119 * * *$ & -0.0046 & -0.0061 \\
\hline & (0.0019) & $(0.0030)$ & $(0.0041)$ \\
\hline \multirow[t]{2}{*}{ Inventory } & $1.6176^{* * *}$ & -0.3212 & 0.6283 \\
\hline & $(0.2219)$ & (0.3017) & $(0.4452)$ \\
\hline \multirow[t]{2}{*}{ Turnover } & $-0.0929 * * *$ & $0.0487 *$ & $0.0891 * *$ \\
\hline & $(0.0175)$ & (0.0269) & $(0.0420)$ \\
\hline \multirow[t]{2}{*}{ Skewness } & $-6.0486 * * *$ & 0.1883 & 0.8757 \\
\hline & (1.7064) & (3.9889) & (7.3208) \\
\hline \multirow[t]{2}{*}{ Return } & -0.0003 & -0.1237 & 0.1657 \\
\hline & $(0.0881)$ & $(0.1176)$ & $(0.2836)$ \\
\hline \multirow[t]{2}{*}{ Constant } & $-0.3918 * *$ & $-3.7107 * * *$ & $-1.0941 * *$ \\
\hline & $(0.1802)$ & $(0.2516)$ & $(0.4458)$ \\
\hline$N$ & 16051 & 16051 & 668 \\
\hline Log-Likelihood & -6343.9038 & -1543.7620 & -436.1722 \\
\hline
\end{tabular}




\section{Appendix 1. Calculation of option intensity}

We estimate option intensity as the sum of the intensity of options granted in the current year, the previously granted and unexercisable options, and the previously granted exercisable options (Core and Guay, 2002). For each type, we use the Black-Scholes (1973) formula for valuing European call options, while also accounting for dividends (Merton, 1973).

$$
\text { Option intensity }=e^{-d t} * N(Z) * \frac{O P T S}{N O S H} * \$ 1,000
$$

where $Z=\frac{\ln \frac{S}{X}+T\left(r-d+\frac{\sigma^{2}}{2}\right)}{S \sqrt{T}} ; N$ is the cumulative probability function for the normal distribution; OPTS is the number of options granted; NOSH is the number of shares outstanding; $\mathrm{S}$ is the price of the underlying stock; $X$ is the exercise price of the option; $\sigma$ is the expected stock return volatility over the life of the option; $r$ is the natural logarithm of the risk-free interest rate; $T$ is the time to maturity of the option in years; and $d$ is the natural logarithm of the expected dividend yield over the life of the option. We aggregate values over executives, including the CEO.

We obtain the risk-free interest rate from CRSP and T (EXDATE), X (EXPRIC), and S (PRCCF) from ExecuComp. For previously granted options, we calculate the exercise price by using the realizable value. We divide the unexercisable (excluding new grants) and exercisable $\quad$ values $\quad$ (OPT_UNEX_UNEXER_EST_VAL and OPT_UNEX_EXER_EST_VAL) by the number of unexercisable and exercisable options held by the executive (OPT_UNEX_UNEXER_NUM and OPT_UNEX_EXER_NUM ). We then subtract these numbers from the firm's stock price as a proxy for the exercise prices (Core and Guay, 2002). The maturity for previously granted options is set equal to the average maturity of newly granted options, -1 for exercisable and -4 for unexercisable options. If the average maturity is not available, we set these equal to 6 and 9 , respectively. 
Finally, $\sigma$ and $d$ are available from ExecuComp prior to 2006 (BS_VOLATILITY and BS_YIELD).

In sensitivity tests, we also use the delta and vega for both the CEO and the remaining VPs, defined as follows:

$$
\begin{aligned}
& \text { Delta }=\frac{e^{-d t} * N(Z) * S}{100}, \\
& \text { Vega }=e^{-d t * N(Z) * S \sqrt{T} * 0.01,}
\end{aligned}
$$

where $N$ is the normal density function, and all other variables are as defined above. 


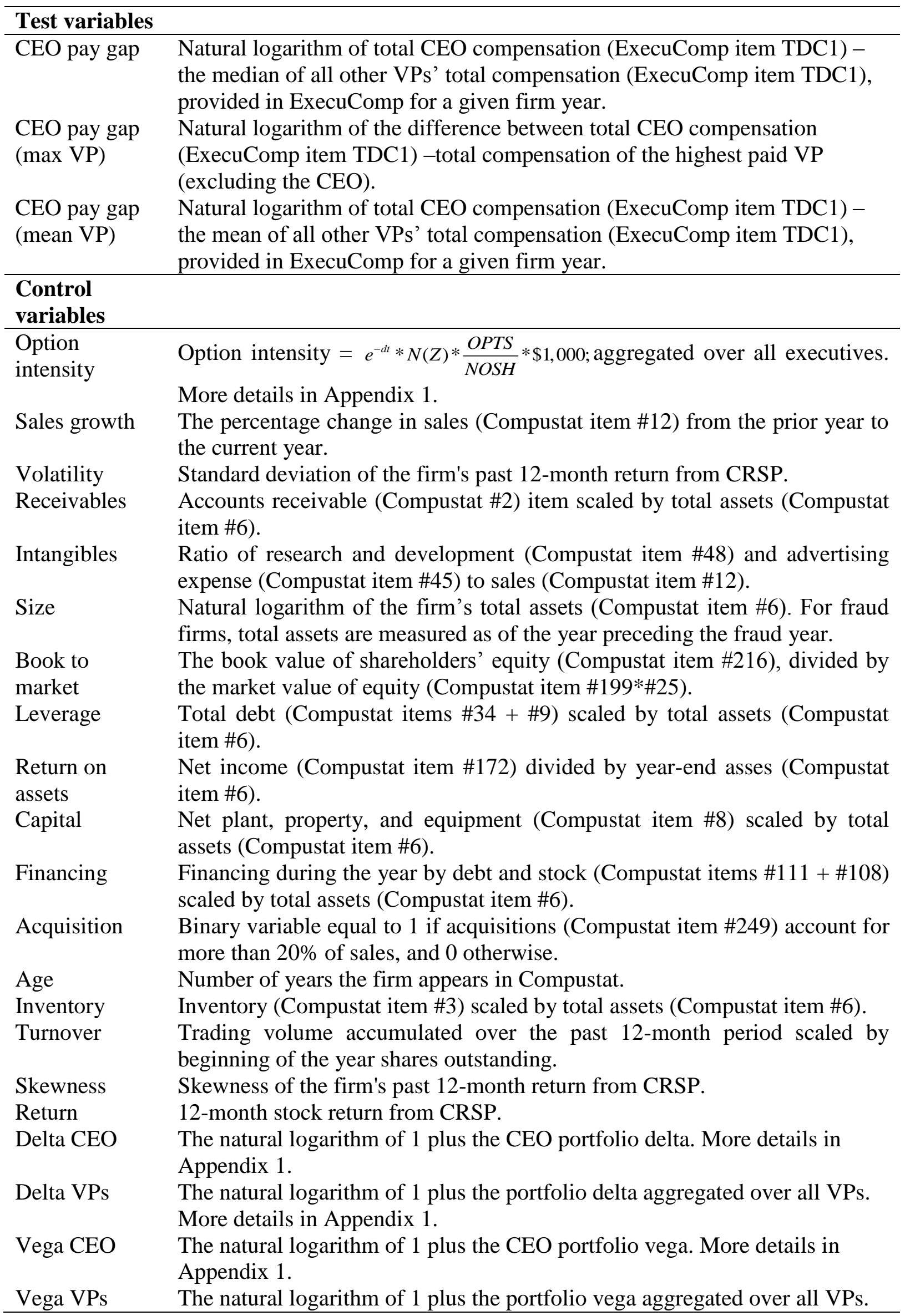


More details in Appendix 1.

Delta CFO The natural logarithm of 1 plus the CFO portfolio delta. More details in Appendix 1.

Vega CFO The natural logarithm of 1 plus the CFO portfolio vega. More details in Appendix 1.

$G$ index The number of anti-takeover-provision (ATP) measures in a firm's charter and in the legal code of the state where the firm is incorporated (Gompers, Ishii, and Metrick, 2003).

Classified A binary variable equal to 1 if the board of directors are elected to staggered

board terms instead of annual terms, and 0 otherwise (Risk Metrics).

CEO duality A binary variable equal to 1 if the roles of chairman and CEO are not separated, and 0 otherwise (ExecuComp).

Independence The number of independent outside directors divided by board size (Risk Metrics).

CEO pay slice CEO total compensation over total VP compensation (ExecuComp item TDC1).

Founder Binary variable equal to 1 if the CEO is also the founder of the company (Feng et al., 2011). 